\title{
Spatio-temporal patterns and environmental controls of small pelagic fish body condition from contrasted Mediterranean areas
}

\author{
Brosset Pablo ${ }^{1,2 \text { ? }^{*}}$, Fromentin Jean-Marc ${ }^{2}$, Van Beveren Elisabeth ${ }^{2}$, Lloret Josep ${ }^{3}$, Marques Virginie ${ }^{2}$, \\ Basilone Gualtiero ${ }^{4}$, Bonanno Angelo ${ }^{4}$, Carpi Piera ${ }^{5,6}$, Donato Fortunata ${ }^{5}$, Čikeš Keč Vanja ${ }^{7}$, \\ De Felice Andrea ${ }^{5}$, Ferreri Rosalia ${ }^{4}$, Gašparević Denis ${ }^{7}$, Giráldez Ana ${ }^{9}$, Gücü Ali ${ }^{8}$, \\ Iglesias Magdalena ${ }^{10}$, Leonori lole ${ }^{5}$, Palomera Isabel ${ }^{11}$, Somarakis Stylianos ${ }^{12}$, Tičina Vjekoslav ${ }^{7}$, \\ Torres Pedro ${ }^{9}$, Ventero Ana ${ }^{10}$, Zorica Barbara ${ }^{7}$, Ménard Frédéric ${ }^{13}$, Saraux Claire ${ }^{2}$
}

${ }_{1}^{1}$ Université de Montpellier, UMR MARBEC (IRD, Ifremer, UM, CNRS), 34203 Sète cedex, France

2 IFREMER, UMR MARBEC (IRD, Ifremer, UM, CNRS), 34203 Sète cedex, France

${ }^{3}$ University of Girona, Faculty of Sciences, 17003 Girona, Spain

${ }^{4}$ Istituto per l'Ambiente Marino Costiero, Consiglio Nazionale delle Ricerche, Mazara, U.O.S di Capo Granitola, via del Mare 3, 91021 Campobello di Mazara (TP), Italy

${ }^{5}$ Consiglio Nazionale delle Ricerche, Istituto di Scienze Marine, Largo Fiera della Pesca, 60125

Ancona, Italy

${ }^{6}$ CEFAS Centre for Environment, Fisheries and Aquaculture Science, Pakefield Road, Lowestoft, Suffolk, UK

${ }^{7}$ Institute of Oceanography and Fisheries, Šet. I. Meštrovića 63, 21000 Split, Croatia

${ }^{8}$ Middle East Technical University, Institute of Marine Sciences Erdemli, Içel, Turkey

${ }^{9}$ Centro Oceanográfico de Málaga (I.E.O.), Puerto Pesquero, 29640 Fuengirola, Spain

${ }^{10}$ Instituto Español de Oceanografia, Centro Oceanográfico de Baleares, Muelle de Poniente s/n,

07015 Palma de Mallorca, Baleares, Spain

${ }^{11}$ Institut de Ciènces del Mar, ICM-CSIC, Passeig Marítim de la Barceloneta, Barcelona, Spain

${ }^{12}$ Hellenic Centre for Marine Research, Institute of Marine Biological Resources and Inland Waters, PO Box 2214, GR 71003 Heraklion, Crete, Greece

${ }^{13}$ Mediterranean Institute of Oceanography (MIO), Aix-Marseille Université/CNRS/IRD/Université de Toulon, UM 110, 13288 Marseille, France

*Corresponding author : Pablo Brosset, email address : pablo.brosset@gmail.com

\begin{abstract}
:
Small pelagic fish are among the most ecologically and economically important marine fish species and are characterized by large fluctuations all over the world. In the Mediterranean Sea, low catches and biomass of anchovies and sardines have been described in some areas during the last decade, resulting in important fisheries crises. Therefore, we studied anchovy and sardine body condition variability, a key index of population health and its response to environmental and anthropogenic changes. Wide temporal and spatial patterns were investigated by analyzing separately data from scientific surveys and fisheries in eight Mediterranean areas between 1975 and 2015.
\end{abstract}


Results showed that anchovy and sardine body condition as well as maximum size in some areas sharply decreased in most Mediterranean areas along years (except in the Northern Alboran Sea). Despite this general pattern, well-marked environmental differences between sub-regions were highlighted by several analyses and variations in body condition were not found to be homogeneous over all the Mediterranean Sea. Further, other analyses revealed that except for the Adriatic where major changes towards a lower body condition were concomitant with a decrease in river runoffs and chl-a concentration, no concomitant environmental regime shift was detected in other areas.

Together, these analyses highlighted the current poor body condition of almost all small pelagic fish populations in the Mediterranean. Yet, global environmental indices could not explain the observed changes and the general decrease in condition might more likely come from regional environmental and/or anthropogenic (fishing) effects. A prolonged state of poor fish body condition, together with an observed reduced size and early age-at-maturity may have strong ecological, economic and social consequences all around the Mediterranean Sea.

\section{Highlights}

- We present a global study of small pelagic fish body condition in the Mediterranean. Fish body condition strongly declined during last decades in almost all studied areas. Body condition did not vary in synchrony between areas in the Mediterranean Sea. Well-marked environmental differences between sub-regions were highlighted. This decline in the condition may have negative effects on ecosystems and fisheries

Keywords : Anchovy, Sardine, Fish health, Marine monitoring 


\section{Introduction}

Overall, ocean Ocean systems are currently going towards changing environmental conditions especially due to the impact of anthropogenic climate change (Hoegh-Guldberg and Bruno, 2010). In particular, the Mediterranean Sea has been identified as one of the most responsive regions to climate change (Giorgi, 2006), as well as to direct human impacts such as pollution (Halpern et al., 2008). Specifically, recent studies using climate models already highlighted the warming of this sea (both at the surface and in deep waters) and the increasing frequency of extreme events (Bethoux et al., 1990; Theocharis, 2008; Vargas-Yáñez et al., 2008, 2010). Large scale perturbations, such as climate change, are known to affect all biological levels, directly (e.g. by affecting physiological thresholds) and/or indirectly (e.g. by modifying food resources; Jørgensen, 1992), resulting in spatio-temporal changes in the abundance of exploited fish in the Mediterranean Sea (see e.g. Lloret et al., 2015b) and elsewhere (see e.g. Drinkwater et al., 2010).

Pronounced small pelagic fish population fluctuations are observed all over the world, especially in the upwelling areas (Baumgartner et al., 1992; Chavez et al., 2003). In the Mediterranean, those variations have been linked to recruitment (Martín et al., 2011), spawning (Agostini and Bakun, 2002; Basilone et al., 2013) or larval survival (Garcia et al., 1998). Such major population changes can have important impacts on the dynamics of marine ecosystems, as these forage fish represent an important biomass at mid-trophic levels, making them a key-component of the ecosystem (Cury et al., 2000; Coll and Libralato, 2012). Thus, the dynamics of this functional group are important both to maintain the integrity of the marine ecosystem, and for socioeconomic stability in the region. The main reason for the renowned population fluctuations of small pelagic is their short life span, as well as their susceptibility to environmental variability (Cushing and Dickson, 1976). Importantly, these characteristics make them excellent indicators of climate-driven environmental changes in marine systems (Drinkwater et al., 2010; Peck et al., 2013). The two most abundant small pelagic fish species in the Mediterranean Sea, the European sardine (Sardina pilchardus) and anchovy (Engraulis encrasicolus), have been exploited for a long time (Lleonart and Maynou, 2003) and are still intensely exploited, accounting for 35 to $50 \%$ of the reported catch in this area (GFCM, 2014). In recent years, a general decreasing trend has been observed in the landings of the small pelagic fish stocks bas ebserved in different parts of the Mediterranean Sea (GFCM, 2012; Vasilakopoulos et al., 2014), leading to an important fisheries crisis. In addition to this, biological alarming biological signals also appeared, such as for example a decrease in growth and body condition of small pelagics in the Gulf of Lions (Van Beveren et al., 2014), as well as the and a higher risk of recruitment failure with increasing temperature highlighted in the Northern Spain area (Maynou et al., 2014).

Body condition is an important individual physiological trait of marine organisms, influencing other life history traits of marine organisms, such as growth, reproduction (e.g. egg size and number, age at first maturity) and mortality (Lloret et al., 2014; Brosset et al., 2016a). Specifically, body condition indices are proxies of the quantity of stored energy, evaluating individual's health status and fitness (Schulte-Hostedde et al., 2001; Wilson and Nussey, 2010). For example, survival, growth and reproductive success are supposed to be theoretically higher for individuals in better condition (Millar and Hickling, 1990), resulting in a particularly an important link between average population body condition in the population and future population success (Jakob et al., 1996; Adams, 1999). Recently, more evidence emerged showing that variations in body condition can affect ecological processes at scales ranging from individuals to ecosystems (Rätz and Lloret, 2003; Lloret et al., 2014; Van Beveren et al., 2014). Consequently, fish body condition can in part determine ecosystem functioning and fisheries yield, so that this factor can constitute a valuable tool in stock assessment and management 
(Lloret et al., 2012). Furthermore, condition indices can be computed easily from collected length and weight data, available in numerous areas and at large temporal scale. It has already been demonstrated that environmental factors, such as temperature, food availability (Brosset et al., 2015b) or parasitism (Ferrer-Maza et al., 2016b) influence fish condition through direct and/or indirect effects. For example, a decrease in body condition due to a lack of food or an increase of metabolic costs under higher temperature has already been advocated in several studies (see e.g. Pörtner and Knust, 2007; Brosset et al., 2015b). Changes in water stratification and currents are known to strongly influence plankton productivity and could thus indirectly act on the body condition of planktivorous small pelagic fish eondition which feed on it (Costalago et al., 2014; Le Bourg et al., 2015; Brosset et al., 2016b). Furthermore, these effects are easily visible because of the fast response of fish condition to environmental changes (Peck et al., 2013).

However, to our knowledge, a large scale study focusing on small pelagic fish body condition has never been realised in the Mediterranean Sea, so that at present it is still unclear if the recent decreases described in a few areas are truly a common issue. In this study, data of anchovy and sardine body condition from nine eight Mediterranean areas were compiled for the first time to compare the temporal trend in body condition of the different studied stocks and to assess whether a general decline took place. We also focused on the environmental (including climatic) factors that could potentially affect fish condition, taking into account spatial factors. A dataset of morphometric (i.e. length and weight) variables of more than 250,000 individuals analysed from 1975 to 2016 enabled us to compute the individuals' morphometric condition index, which assumes that for a given length a heavier fish is in better condition.

\section{Material and Methods}

\subsection{Study areas}

Mediterranean sub-areas (GSA) were selected following the General Fisheries Commission for the Mediterranean (GFCM) delimitations adopted for stock assessments from the western-most Alboran Sea to the Black Sea in the East (Fig. 1). The Mediterranean Sea is known to be oligotrophic, even if an important variability in productivity is visible with a West to East gradient and enhanced primary productivity areas due to strong river discharge as in the North Western Mediterranean, with the Rhone in the Gulf of Lions and the Ebro in the Catalan Sea, or the Po river in the Northern Adriatic Sea.

In the North Western part of the Mediterranean Sea the Gulf of Lions is the most productive area and covers about $20400 \mathrm{~km}^{2}$ (Bănaru et al., 2013). This area has a wide continental margin $(>60 \mathrm{~km})$ and productivity depends on strong mixing events induced by NW and N winds and Rhodanian inputs which create a $\ldots$ A gradient of nutrients takes place from East to West due to the Rhodanian inputs tocated to the East of the area-(Darnaude et al., 2004). Also, local upwellings support the high productivity (Millot, 1990). The Northern Spain area, grouping the Catalan Sea and the Gulf of Valencia, is oceanographically connected with the Gulf of Lions through the Northern current flowing to the south-west which enhances the production in the north Catalan Sea. Models have indeed highlighted larval connectivity between the northern spawning grounds of anchovy in the Gulf of Lions and the Catalan Sea due to the hydrodynamic characteristics in the area mediated by the North current and the filament transport in mesoscale eddies (Ospina-Alvarez et al., 2012). The north Catalan Sea has a narrow shelf that widens in front of the Ebro river delta ( $>60 \mathrm{~km}$ wide) where it is strongly influenced by water discharge and wind mixing allowing phytoplankton to find necessary 
nutrients, especially during summer period when the water column is strongly stratified (Palomera $e t$ al., 2007).

In the south of Spain, the Northern Alboran Sea is the southern- and western-most area in our study, and it is a transitional zone between Mediterranean and Atlantic waters. Two gyres, occurring in the central basin of the Alboran Sea, as well as several upwellings in the north coast associated with vertical and lateral nutrient inputs, make this area especially productive (Macías et al., 2008).

The Adriatic Sea was divided into two areas: the Northern Adriatic Sea and the Southern Adriatic Sea. The Northern Adriatic is characterized by shallow depths and high river discharge, particularly due to the Po River outflow, which has a major impact on the phytoplankton biomass due to the high nutrients loads (Artioli et al., 2008). Furthermore, local upwelling events and eddies, that contribute to spread the Po river discharge offshore, enhance the primary production (Russo and Artegiani, 1996). A decreasing trend in nutrient concentration and in production is observed from North to South (Zavatarelli et al., 1998): the Southern Adriatic is in fact deeper, mostly influenced by eastern Mediterranean waters and exhibits an oligotrophic character with lower phytoplankton abundance and biomass (Zavatarelli et al., 1998).

The Strait of Sicily is the area where the Western and the Eastern Mediterranean basins connect, playing a crucial role in determining the water-mass exchanges. Main water masses present in the Strait of Sicily might be divided into a surface layer composed of Atlantic water flowing eastwards, and intermediate and deep layers mainly composed of Levantine intermediate water, and transitional Eastern Mediterranean deep water flowing in the opposite direction. Their encounter creates local upwellings which enrich the upper water layers, enhancing primary production and creating favorable environmental conditions for small pelagic fish (Basilone et al., 2013; Bonanno et al., 2014).

The North Aegean Sea is among the most productive areas of the Eastern Mediterranean Sea. Black Sea waters, river runoffs and the large continental shelf contribute to increase primary productivity in this area, explaining the high small pelagic catches and the importance as a spawning ground for both anchovy and sardine.

In the Eastern part of the Mediterranean, the North Levant Sea is characterized by the highest temperatures in the Mediterranean, together with high salinity values and extreme oligotrophy.

The Black Sea is almost completely isolated, being connected to the Mediterranean only through the Bosphorus Strait. It is therefore mostly influenced by freshwater inputs from rivers (Özsoy and Ünlüata, 1997) and it is characterized by tow weak water circulation and anoxic waters below the oxycline at about 150 meters depth. Only anchovy is found in the Black Sea, where this species is known to migrate between the North, where they reproduce and feed, to and the South, where they overwinter (Gucu et al., 2016). 


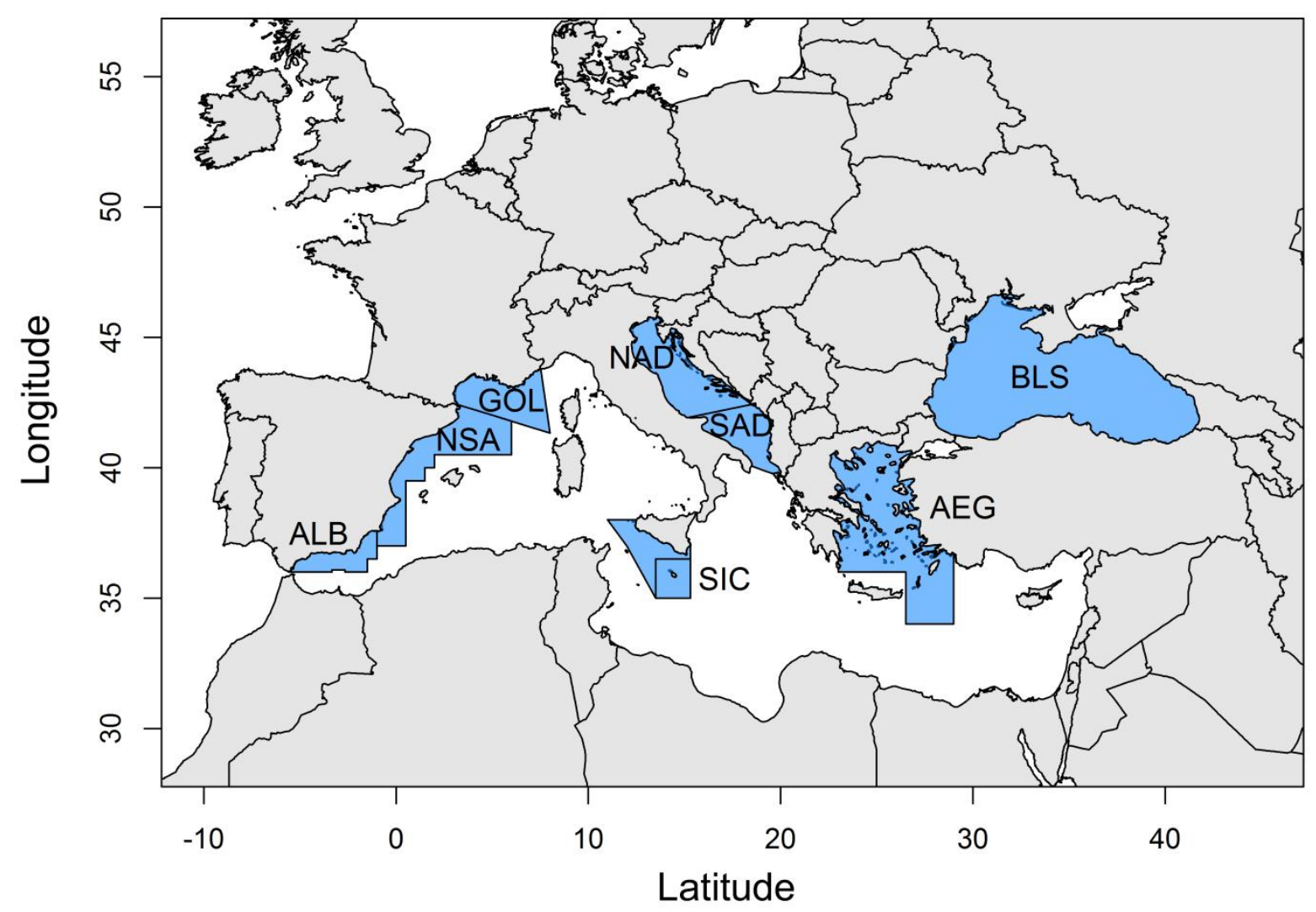

Fig 1. Main Geographical Subareas of the Mediterranean and Black Seas used in this study according to their number defined by the General Fisheries Commission for the Mediterranean (NAD: Northern Alboran Sea; NSA: Northern Spain area; GOL: Gulf of Lions; SIC: Strait of Sicily (Malta Island and South of Sicily areas combined); NAD: Northern Adriatic Sea; SAD: Southern Adriatic Sea; AEG: Aegean Sea; BLS: Black Sea).

Fig 1. Main Geographical Subareas of the Mediterranean and Black Seas used in this study according to their number defined by the General Fisheries Commission for the Mediterranean (1: Northern Alboran Sea; 6: Northern Spain area; 7: Gulf of Lions; 16: Strait of Sicily (gathered GSA 15 and 16 combined); 17: Northern Adriatic Sea; 18: Southern Adriatic Sea; 22: Aegean Sea; 29: Black Sea).

\subsection{Fish sampling}

Two types of sampling were done. One used commercial vessels (pelagic trawlers and/or purse seiners) all over the year and the other, scientific surveys at sea (trawls), carried out once per year and dedicated to small pelagic fish abundance estimation (Mediterranean International Acoustic Survey (MEDIAS) since 2009). During the acoustic surveys fish were caught with pelagic trawls. Summarized information on fish sample sizes, temporal coverage and month of collection are provided in Table 1. During scientific surveys, parallel fixed transects perpendicular to the coastline were followed each year collect data in the same area. Echosounders enabled to detect fish traces and a pelagic trawl was deployed to determine fish composition when these traces were long enough. The same protocol was adopted for both types of samples. Regardless of the sampling method, a A random sample of anchovies er and sardines from the catch was directly measured on board or brought to the lab on land for subsequent analyses. Fish measurements included fish total length (TL, depending on the area from the nearest $\mathrm{mm}$ to the nearest $0.5 \mathrm{~cm}$ for the scientific survey or from the 
nearest $\mathrm{mm}$ to nearest $\mathrm{cm}$ for commercial samples) and total weight (W, to the nearest $\mathrm{g}$ for both types of sampling).

\subsection{Condition and maximum size estimations}

\section{Morphometric index of condition}

Condition factors are mainly based on length-mass relationships (Bolger and Connolly, 1989). While Fulton's condition factor assumes isometric growth or growth without changes in body proportions, resulting in condition factors that are often length- and species-dependent, the relative condition factor according to Le Cren (1951) compares actual weight to a standard weight predicted by weight-length regression, based on the population from which the fish was sampled (Basilone et al., 2006; and references therein).

As the two studied species exhibited an allometric growth pattern (Brosset et al., 2015a), we used for this study the more suitable relative condition index $\left(K_{n}\right.$, Le Cren, 1951) rather than Fulton's index:

$$
K_{n}=W / W_{r}
$$

where $\mathrm{W}$ is the observed weight of an individual and $W_{r}$ the predicted weight of an individual of a given length $\mathrm{TL}$ calculated with $\left(W_{r}=\alpha \mathrm{TL}^{\beta}\right)$. By definition, the values of the relative condition factor are distributed around 1 and the higher the value the better the condition.

To investigate temporal fluctuations, length-weight relationships were computed separately for each area and species. Yet, during spatial analysis, all individuals belonging to anchovy or sardine were pooled together to estimate the $\alpha$ and $\beta$ parameters of a single non-linear regression per species. Length-weight relationships were computed by area and species to investigate temporal fluctuations and only by species for the spatial analyses. The advantage of a single regression curve for all individuats of one per species is the possibility to compare the values between the different stocks areas (i.e. standardization of the indicators are standardized for inter-ecosystem comparisons).

As recommended shown by several authors (Schulte-Hostedde et al., 2005; Stevenson and Woods, 2006; McPherson et al., 2011), this morphometric index is related to total lipid content, and its use has previously been validated for individuals outside the reproductive period. During the reproductive period, the variations of condition reflect both lipid and protein variations which represent a global measure of condition (Brosset et al., 2015a).

Maximum size of both species was estimated each year by computing the $95 \%$ quantile of fish size distribution rather than the maximal size observed, making this parameter less sensitive to extreme individuals.

\subsection{Environmental data}

Daily sea surface temperature (SST, in $\left.{ }^{\circ} \mathrm{C}\right)$, chlorophyll $a\left(\mathrm{Chl}-\mathrm{a}\right.$, in $\left.\mathrm{mg} \cdot \mathrm{m}^{-3}\right)$ and Eddy kinetic energy (Eke, measuring turbulence in $\mathrm{cm}^{2} \cdot \mathrm{s}^{-2}$ ) were obtained from satellite data. These three environmental variables were chosen due to their large coverage in space and time and because they are relevant to explain differences in productivity, water mixing and temperature patterns affecting fish body condition. SST came from version 5 of the AVHRR Oceans Pathfinder SST data set obtained from the NOAA website (http://podaac.jpl.nasa.gov). Surface chlorophyll $a$ was similarly extracted using MODIS-aqua data from the OceanColor web site (http://oceancolor.gsfc.nasa.gov). Kinetic energy was extracted from Aviso database. All variables were extracted on the basis of the different area coordinates given by the GFCM. The discharges of three main rivers of the northern Mediterranean, i.e. the Ebro (Northern Spain area), the Po (Northern Adriatic sea) and the Rhône (Gulf of Lions) were 
used in the breakpoint analysis (see below) to detect any synchrony between river's discharges and fish condition. Note that rivers that discharge in the Black Sea were not considered, as time series of fish condition in the Aegean Sea and Black Sea are too short or too discontinued to conduct such an analysis. A monthly average was taken for all environmental variables per area. Despite the fact that salinity and zooplankton data may be relevant, this type of data was too scarce or heterogeneous in the different Mediterranean areas to be considered. Finally, we also used suitable large-scale climatic indices for the Mediterranean area, such as the Western Mediterranean Oscillation (WeMO, MartinVide and Lopez-Bustins, 2006), the North Atlantic Oscillation (NAO, Hurrell and Loon, 1997), the Mediterranean Oscillation (MO, Conte et al., 1989) and the Atlantic Multidecadal Oscillation (AMO, Kerr, 2000) indices. These indices are based on the differences in normalized sea level pressures between two areas and were used as broad scale environmental descriptors. Because most of the variability patterns in the NAO, WeMO or AMO indices takes place during winter (see Hurrell, 1995; Martin-Vide \& Lopez-Bustins, 2006), the averages of winter monthly values (December to March) from the previous year were used. All these variables were averaged monthly over each area.

\subsection{Data analyses}

\subsubsection{Fish body condition and maximum size time series analysis}

All-Fish body condition and maximum size time series from annual scientific surveys were analysed together to identify the main characteristics of the time series, as well as to compare them. Correspondence in terms of trend, periodicity or breakpoints among the different areas could indicate that small pelagic fish condition or size exhibits common patterns of temporal variation at the Mediterranean scale. As the Spanish scientific survey shifted from winter to summer in 2009, we accounted for this change by calculating the mean annual body condition cycle of each species from to fisheries data and then-by adding the obtained winter/summer difference to the winter values (i.e. before 2009). This allowed having a continuous time series from 1993 to 2013 with comparable values before and after 2009 .

\section{Trends, periodicity and annual cycle of body condition}

Twelve MEDIAS (Northern Alboran Sea, Northern Spain area, Gulf of Lions, Northern Adriatic Sea, Southern Adriatic Sea and Strait of Sicily, Table 1.) and two fishery time series (Adriatic) were long enough (between 13 and 23 years) to investigate temporal changes for both species. The Aegean Sea and the Black Sea could not be considered in the time series analyses because they were far too short (containing only 5 and 3 years of data with one point per year, respectively, see Table 1.). In order to fill some existing gaps in the time series, interpolations had to be applied using cubic splines or linear interpolations. For the other time series, the missing values were filled using either cubic splines or linear interpolation when the analyses imply time continuity.

The different condition time series for both species and each location were analyzed to detect potential long term trends wh Eigen vector filtering (EVF, Colebrook, 1978). This method was us to estimate the general trend of each time series, and to estimate the percentage of variance explained by each one of these trends. Briefly, for each time series, an autocovariance matrix was constructed by shifting the series between 1 and 4 years (to retain fluctuations beyond the seasonal signal). The series' trend is computed by a principal component analysis performed on this matrix (use of its first axis).The Eigen vector filtering (EVF, Colebrook, 1978) was performed on the condition time series for both species at all locations to estimate the percentage of variance of the long-term trend in each series (see Ibanez and Dauvin, (1988) for more details).

Periodicity analyses on the other hand were only performed on fisheries data from the Adriatic Sea, which displayed the only long-enough monthly time series for both species (from 1975 to 2012). 
Fishery time series exist for the Northern Alboran Sea (2003-2013), the Northern Spain area (20042013) and the Gulf of Lions (2005-2016) but were considered not long enough to be used in this type of analyses. To do so, wavelets analyses were used, which this analysis not only decomposes the variance of a time series over frequencies, but it does it alse and over time domains and tolerates nonstationary data. To detect low and high frequencies, $\beta$ surrogate test were used since it is deemed to be well-suited to ecological time series (for more details, see Rouyer et al., 2008). Further details on the methodology can be found in Van Beveren et al., (2016). Final wavelet power spectra were presented as time-frequency plots, with colors indicating intensities of match between wavelets and time series (from blue=low variance to grey=high variance). Additionally to periodicity analyses, temporal changes in the timing of the annual peak of condition in the Adriatic Sea were investigated. The timing of the peak of body condition was computed as the mean number ( 1 for January, 2 for February, etc) of the three months with highest condition during each year where all data were available (no year had two peaks of condition that would have affected this calculation).

\section{Covariability of small pelagic fish body condition in the Mediterranean}

In order to know if similarity in fish body condition was dependent on space, more precisely on distances between sites where the time series come from, we computed pairwise correlations (Mantel test, Mantel, 1967) among fish body condition time series from fisheries data and plotted them again distances (in $\mathrm{km}$ ) between sites. A nonlinear model was fitted to compute the distance where correlations are reduced to $50 \%$ of the estimated correlation at a distance of $0 \mathrm{~km}\left(d_{0.5}\right.$, see Batchelder et al., 2012 for further details). We accounted for year-to-year temporal autocorrelation by using estimated numbers of effective degrees of freedom (typically $\sim 10 \%$ smaller than the number of years in the time series) instead of removing autocorrelation by difference filtering (Pyper and Peterman, 1998).

\subsubsection{Linking Investigating environmental changes to and fish condition relationships}

To investigate potential synchrony in temporal changes in fish condition and environmental variables, we computed a breakpoint analysis, i.e. a date (in year) that distinguishes two continuous periods of significant different levels in a given variable. Fish condition and size time series were analyzed using the strucchange package (Zeileis et al., 2013) to assess the year(s) (and their 95\% confidence intervals) of statistically significant changes in the level ef subsets of fish condition time series. The Bayesian Information Criterion (BIC) was consulted to assess a penalty for the number of segments used to describe the data and thus have an objective criterion to determine the most parsimonious number of breakpoints. We performed this test analysis for each species and area in order to check if there was a synchrony between the fluctuations of small pelagic fish condition in different Mediterranean Sea areas. The same method was used to detect environmental breakpoints (SST, Chl-a, Eke, rivers and climatic indices) and check their synchrony with fish biological parameters breakpoints.

A principal component analysis (PCA) was implemented to describe the multivariate relationships among the annual values of both fish biological parameters (fish body condition and maximum size) and main environmental factors (SST, Chl- $a$ and Eke). A correlation-based matrix on Euclidean distances among all variables was used. The PCA reduced the spatial population and environmental variability into a few dimensions. Since sardine is not present in the Black Sea, this area was not considered in the sardine PCA.

All statistical analyses were performed with R version 3.0.2 (R Development Core Team, 2013). Values are indicated as mean \pm standard error (SE) and all statistical tests were performed at a significance level of 0.05 . 


\section{Results}

\section{Annual fish condition and maximum size trends}

Anchovy and sardine mainly displayed a decreasing trend in their body condition in most studied areas (Fig. 2). Anchovy body condition decreasing trend was really showed a pronounced decrease in the Gulf of Lions (63\% of deviance explained), in both Adriatic Sea areas ( $72 \%$ and $78 \%$ of deviance explained in the North and South part, respectively) and in the Strait of Sicily (60\% of deviance explained). While the decreasing trend has been linear along years since 1998 in the Southern Adriatic Sea, anchovy condition has really started to drop only since 2004 in the Strait of Sicily and in the Northern Adriatic and since 2007 in the Gulf of Lions. Weaker trends Anchovy body condition was increasing before being stable in the Northern Alboran Sea and stable over the time series in the Northern Spain area (43\% and $46 \%$ of deviance explained). were highlighted in the Northern Spain area and in the Northern Alboran Sea for anchovy, emphasized by the lower explained deviance ( $46 \%$ and 43\%, respectively). All areas except the Northern Alboran Sea displayed an overall decreasing trend for sardine body condition (Fig. 2). Similarly to anchovy, the decrease was mostly linear in the Southern Adriatic, and began later in the 2000s in other areas (in 2004, 2007, 2007 and 2009 in respectively the Northern Spain area, the Gulf of Lions, the Northern Adriatic and the Strait of Sicily, Fig. 2). The deviance explained by this trend was relatively high in all these areas (from $57 \%$ to $85 \%$ ), except for the Strait of Sicily where it only explained $49 \%$ Sicily. The trend was different in the Northern Alboran Sea, where sardine body condition was stable before it greatly increased during the last two years (Fig. 2).

As for fish condition, the Northern Alboran Sea did not exhibit pronounced trend in fish maximum size and the same applies to the Northern Spain area (between 40 and $50 \%$ of deviance explained, Fig. 3 ). The Gulf of Lions (especially after 2008), and Northern Adriatic (linearly) on the other hand showed a strong negative trend for both species and a high percentage of deviance explained (Fig. 3). The decrease was also observed but less pronounced in the Southern Adriatic Sea (Fig. 3). Finally, a decrease in sardine size only was found in the Strait of Sicily, though not really strong $(49 \%$ of deviance explained, Fig. 3). 


\section{Anchovy}
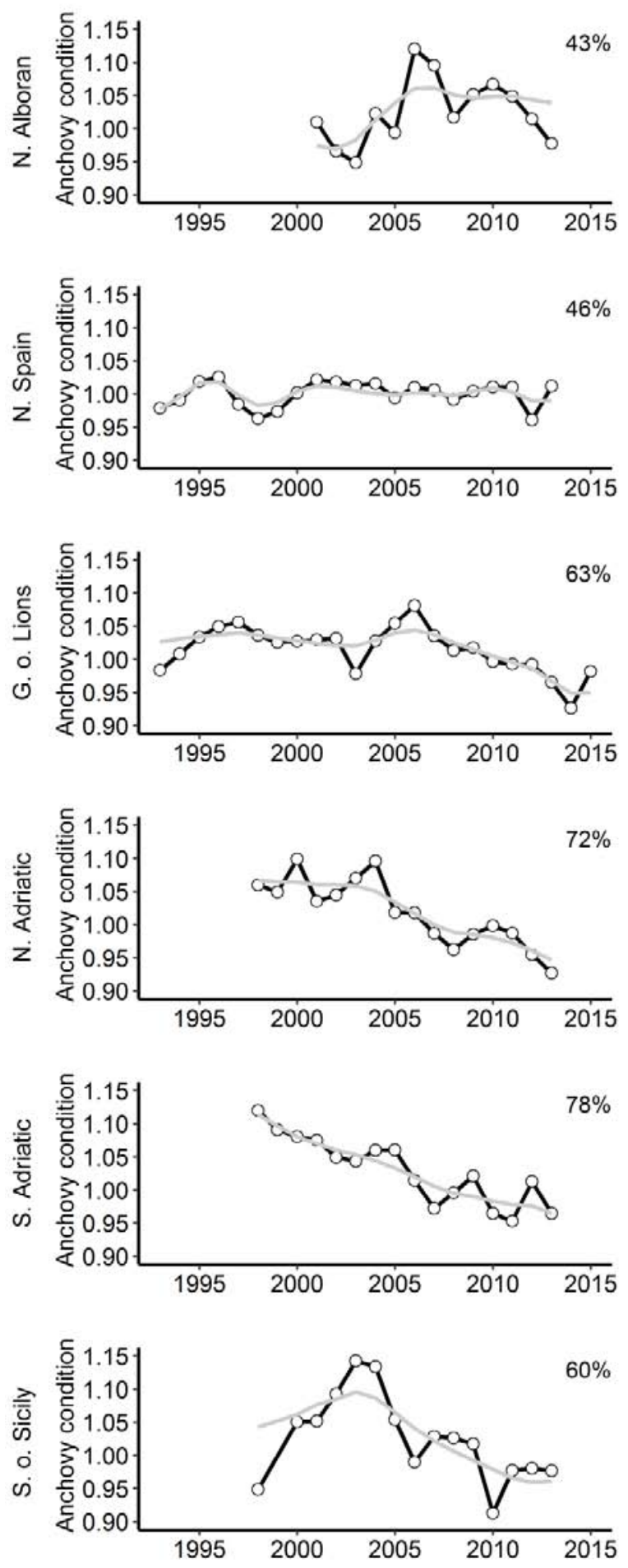

Sardine
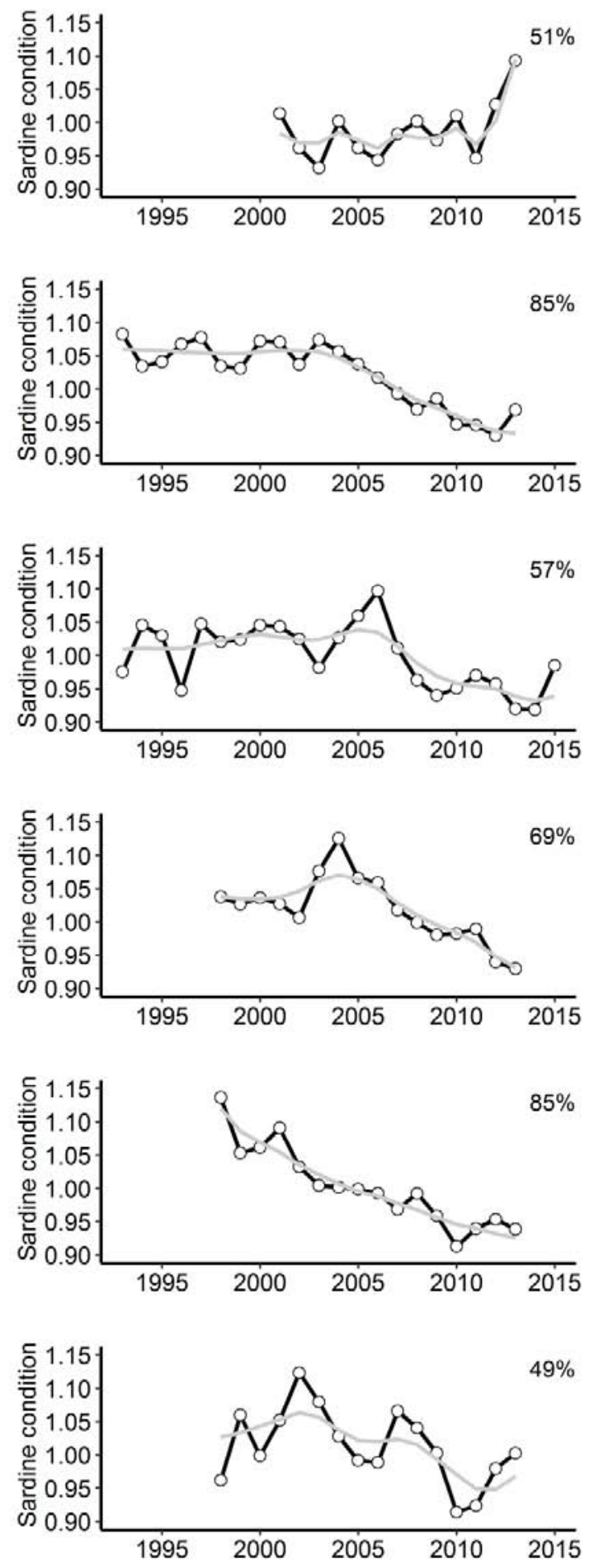

Figure 2. Time series of the annual anchovy and sardine body condition of the six different areas studied from MEDIAS data. The black line with markers represents the time series and the grey line the trend from Eigen Vector Filtering. The percentage of deviance explained by the main trend is indicated in the upper right corner. 
Anchovy
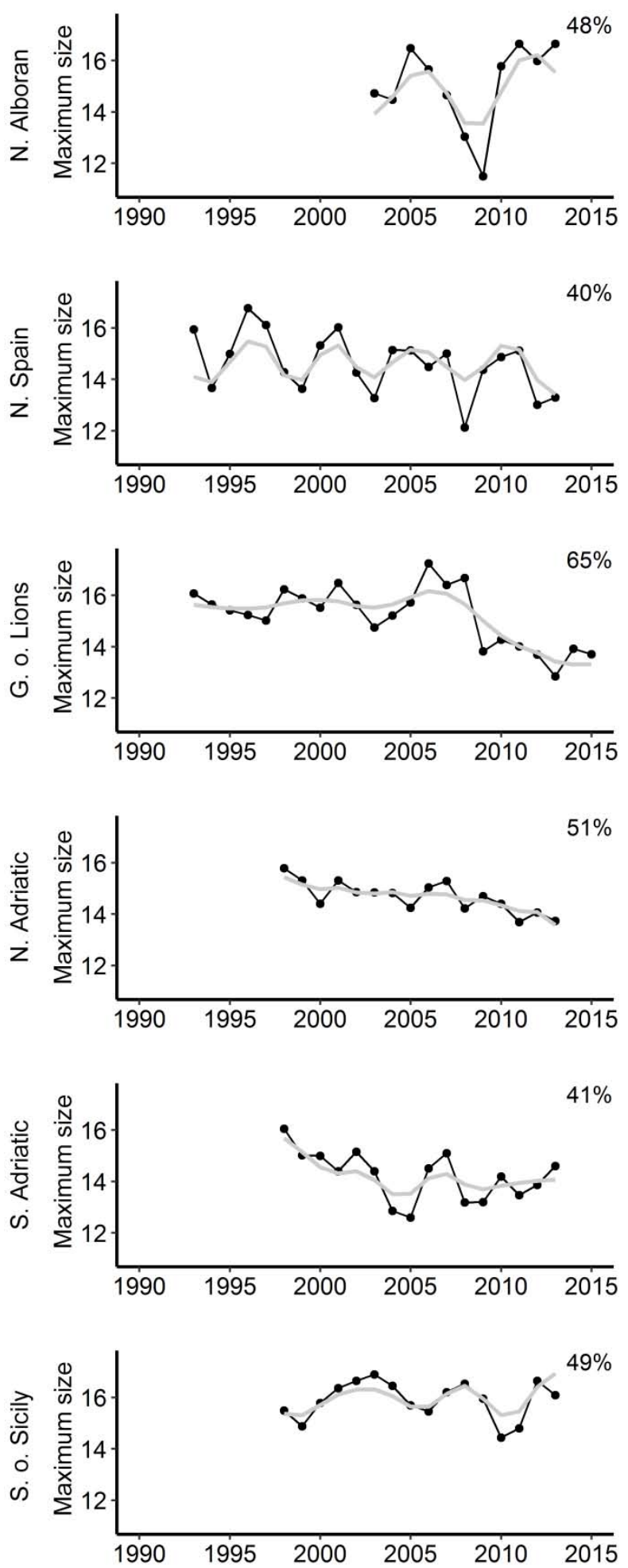

Sardine
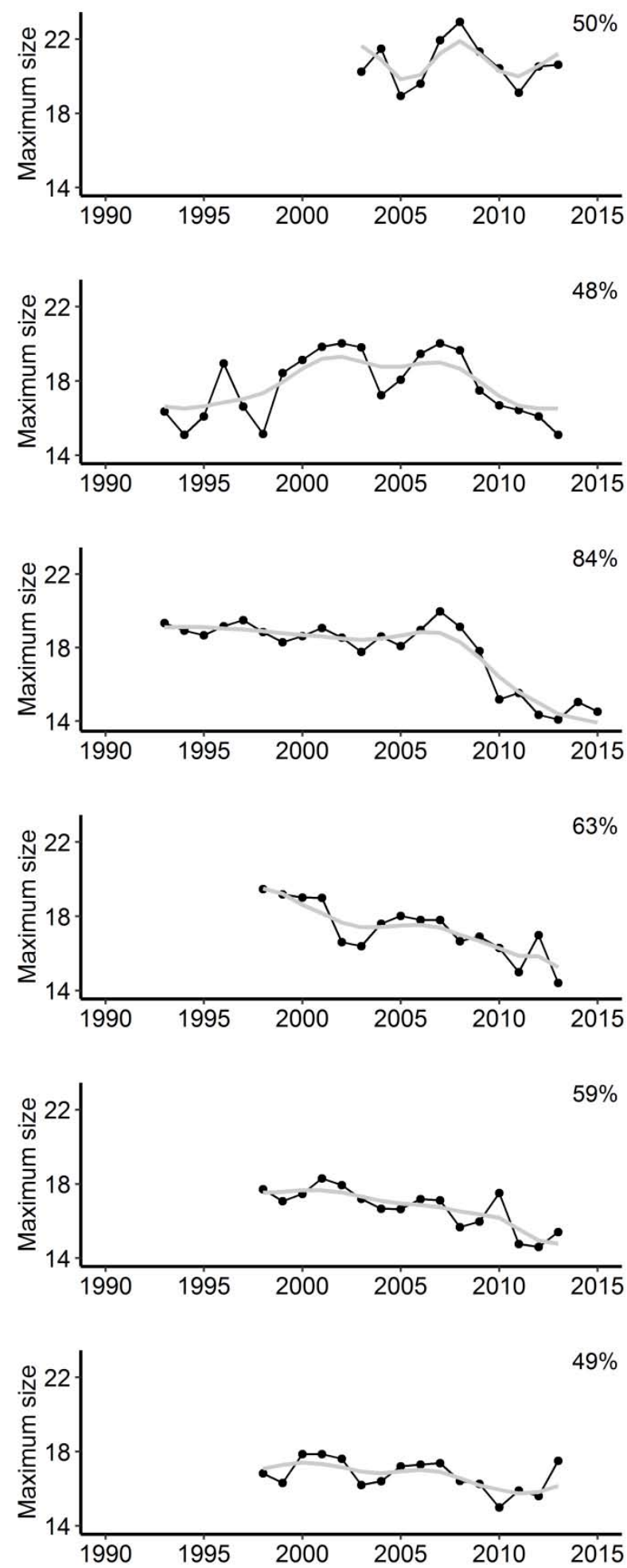

Figure 3. Time series of the annual anchovy and sardine maximum size of the six different areas studied from MEDIAS data. The black line with markers represents the time series and the grey line the trend from Eigen Vector Filtering. The percentage of deviance explained by the main trend is indicated in the upper right corner. 


\section{Fish body condition, size and environmental breakpoint analysis}

The significant cChanges of in fish condition oceurred in the middle of the 2000's in most per species and Mediterranean Sea subareas as indicated by breakpoint analyses occurred in the middle of the 2000's. Indeed, almost Fish body condition time series showed between zero and two statistically significant breakpoints, which mostly occurred in the middle of the 2000's (Fig. 4)., minimum condition values always occurring during the last years when breakpoints were detected. Moreover, breakpoints were not always detected for each environmental time series. In particular, and this is especially true for the Eke, the climatic indices (except $A M O$ in 1995) and sometimes the chl $a$ in certain areas which did not display any discontinuity (Fig. 4). The last breakpoints in sardine condition (consistently towards lower condition values) occurred simultaneously between 2006 and 2008 in all areas (except in the Northern Alboran Sea and the Strait of Sicily where no breakpoint occurred, Fig. 4). Regarding anchovy, the last breakpoints were much more widely spread in time between 2005 and 2009 (Fig. 4). The intensity of the drop in condition during the last breakpoint varied between areas and was lower in the Gulf of Lions and the Southern Adriatic for anchovy with a decrease of $6 \%$ in body condition compared to the Northern Adriatic and the Strait of Sicily where the decrease was about 8\% for anchovy. Sardine condition dropped less in the Southern Adriatic (5\%) compared to the Gulf of Lions, the Northern Adriatic and the Strait of Sicily where the loss of condition was between 8 and $9 \%$. Breakpoints in maximum fish size appeared in the areas where fish body condition have also shifted and often occurred simultaneously or just after those ones (Fig. 4). Regarding the environment, no breakpoints were detected in either the Eke time series, nor in the climatic indices (except for AMO in 1995) nor in the chl- $a$ concentration of certain areas (Fig. 4). Depending on the area, SST had one or two breakpoints. The first ones co-occurred around 1996 while the second one only occurred in 2006 in Sicily and in 2010 in both Adriatic areas. The three river discharges also showed breakpoints, the first one being similar around 2002 but the second one only occurred in the Adriatic in 2008 (Fig. 4). In the Northern Adriatic, the anchovy decreasing body condition led to a breakpoint in 2004, which coincided with the decline in Po river runoff and chl-a for which breakpoints have been also detected in the same period, in 2002 and 2003, respectively (Fig. 4). At the same time, the sardine eondition increased (Fig. 4). The second breakpoint of decreasing in sardine condition (reflecting a drop) co-oceurred with a rapid rise in chl a (Fig. 4). In the Northern Adriatic, the anchovy decreasing body condition led to a breakpoint in 2004, which coincided with the decline in Po river runoff and chl- $a$ for which breakpoints have been also detected in the same period, in 2002 and 2003, respectively (Fig. 4). The breakpoint in sardine condition reflecting a drop occurred in 2006 (Fig. 4). In the Southern Adriatic, the both anchovy decreasing breakpoint co-occurred with a decrease in chl- $a$. Sardine's first decreasing breakpoint co-occurred with a decrease in chl- $a$ while the second sardine condition decreasing breakpoint co-occurred with an increase of temperature (Fig. 4). Apart from the Adriatic, only two breakpoints of fish body condition and size time series co-occur with any environmental breakpoint (Fig. 4). An increase in sardine size occurred with increasing SST in the North Spain area while a decreasing anchovy body condition has been concomitant with decreasing chl- $a$ quantity and increasing SST in the strait of Sicily (Fig. 4). 


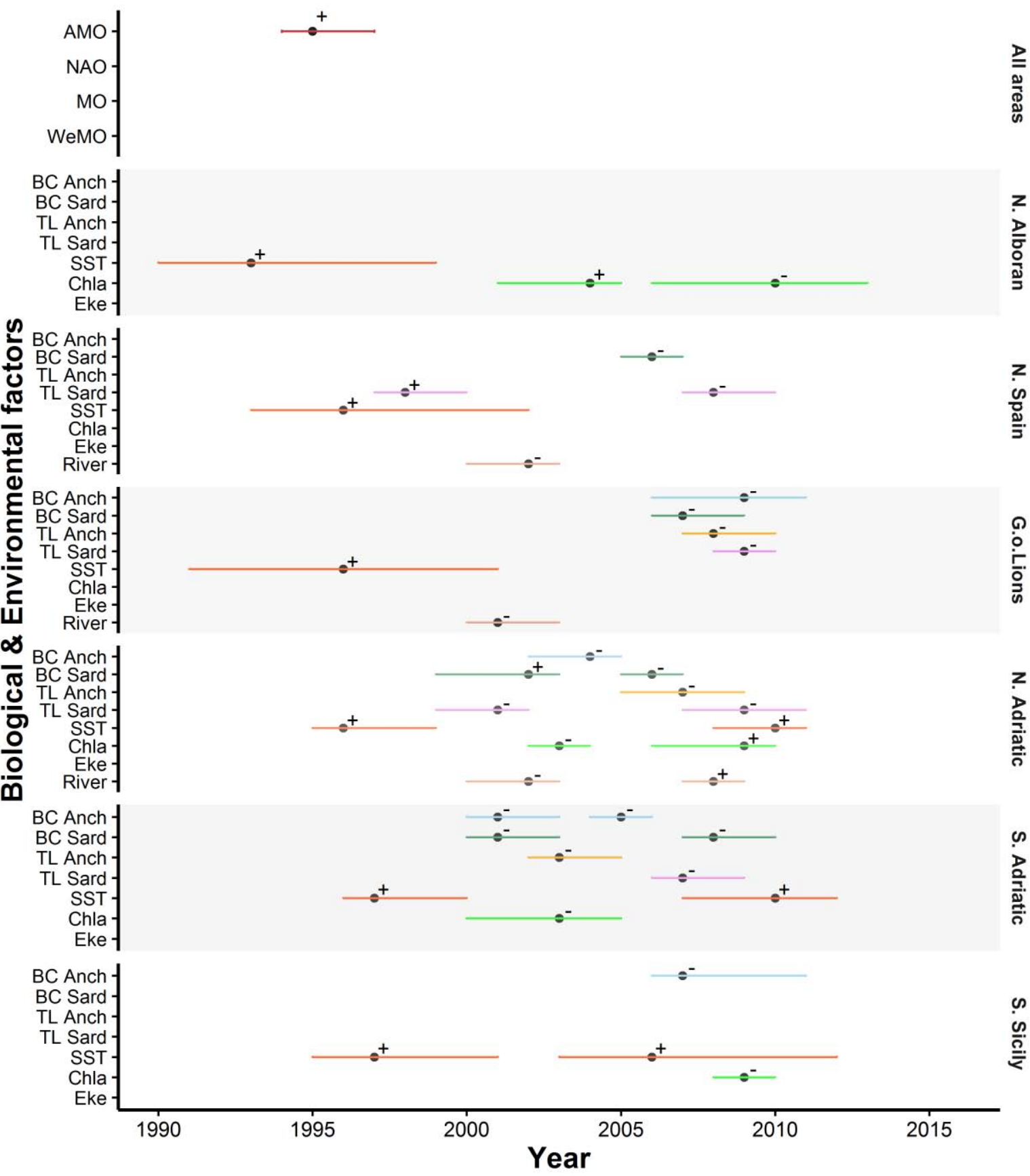

Figure 4. Breakpoint analyses of fish biological parameters from MEDIAS data and environmental factors time series per Mediterranean Sea region (BC and TL mean body condition and total length, respectively). Horizontal lines indicate the confidence interval around the detected breakpoint and the sign (plus or minus) indicated the direction of the breakpoint toward an increase or a decrease. 
Time series of monthly body condition from 1975 to 2012 derived from fisheries data in the Adriatic Sea displayed long term decreases. A first drop occurred in the mid-80s for both species. It is followed by a slight decrease (1995) and increase (2005) for anchovy and a final decrease between 2008 and 2012 only for sardine, but with a proportion of deviance explained smaller than for seientific data (from $42 \%$ to $48 \%$ of deviance explained, Fig. 5A). Periodicities at lower frequency were also observed for anchovy with periods of 3 years between 1996 and 2012 or 6-7 years between 1975 and 1995 (Fig. 5A). Periods of 6-7 years were detected all along the temporal windows in sardine body condition (Fig. 5A). The seasonat annual cycles all along during the entire period is well pronounced, as revealed by wavelet analyses (Fig. 5A), but the peak in condition moved earlier in the season for both species along the series, with a stronger change for anchovy (from October/November in the 1970's to June/August in the 2000's) than for sardine (from September/October in the 1970's to July at the end of the 2000's, Fig. 5B). (periods up to 6 years for both species, Fig. 5A).
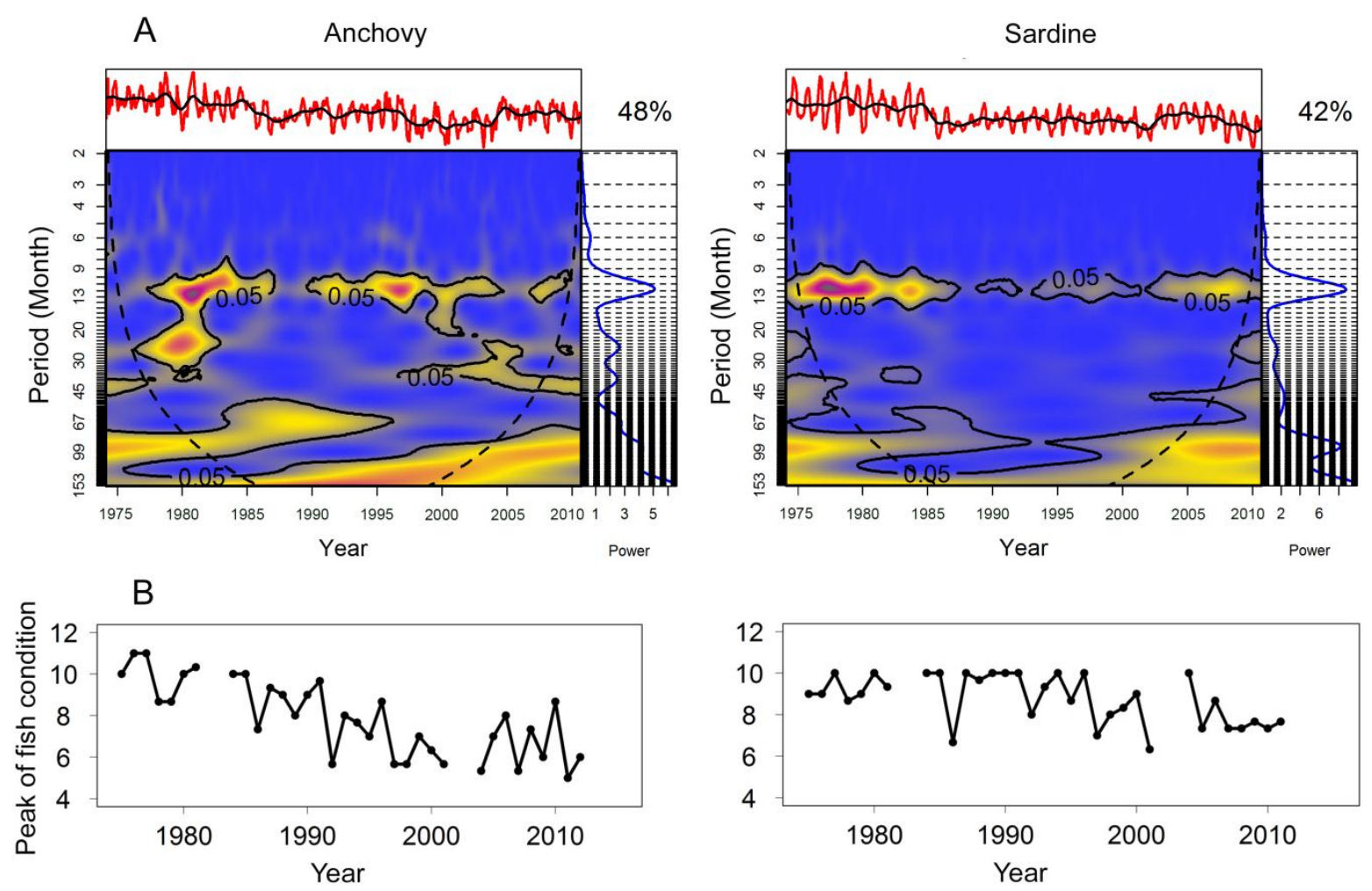

Figure 5. Wavelet analyses and timing of the peak in condition analyses for the anchovy and sardine body condition time series-from Adriatic fisheries data. In the part A) the main panels are the wavelet power spectra (mean panels). Power values range from blue (low) to grey (high). The black dashed line forming a cone delimits the region not influenced by edge effects. Continuous black lines show $5 \%$ significance areas. The top panel represents the standardized data time series (in red) as well as the EVF result (in black). The right panel is the global spectrum. The part B) is the yearly evolution of the moment of the maximum fish condition. Peaks were calculated as the average of the three successive months of highest condition values. 
Environmental parameters determining pelagic fish body condition in the Mediterranean

In the PCA performed on anchovy body condition, maximum size and environmental factors, the first (F1) and second (F2) components accounted for respectively $40 \%$ and $22 \%$ of the total variance (Fig. 6). Positive values of F1 represented areas with high mean annual SST while positive values of F2 indicated areas with high mean annual chl- $a$. and fish biological parameters (maximum size and eondition). Anchovy mean annual body condition and maximum size were positively and closely linked-related to mean annual Eke rather than to mean annual chl- $a$ and temperature in the Mediterranean Sea. In the PCA performed on sardine, F1 and F2 represented 37\% and 28\% of the total variance, respectively (Fig. 6). F1 represented the contrast between mean annual temperature and mean annual chl- $a$, while F2 represented mainly is mostly characterized by the mean annual Eke. Points were grouped mainly by GSA, similar to as for anchovy. Contrary to anchovy, sardine annual body condition and maximum size were strongly related to annual mean chl- $a$, opposed to annual mean temperature and almost independent of Eke. For both species, even if interannual variability within areas was sometimes important (e.g. Northern Alboran Sea), points of a same area were closer to each other than to points from other areas, indicating a spatial variability much higher than the temporal one (Fig. 6). This regional coherency was especially visible for sardine where areas were ordered according to the latitudinal gradient (from South to North) on the first component and where the northern the area, the higher the sardine body condition (except for the Northern Alboran Sea, Fig. 6). Particularly, the Strait of Sicily and the Northern Alboran Sea were totally isolated, mainly due to their strong Eke values. A last point of interest relies on the discrimination of the different areas, such as the Gulf of Lions against the Alboran Sea for sardine or Sicily against Northern Adriatic for anchovy (Fig. 6), which indicates that regions inhabited by anchovy and sardine display different environmental conditions.

\section{Covariability of small pelagic fish body condition in the Mediterranean}

Covariability of both anchovy and sardine body condition declined exponentially with increasing distance between harbors, as expected (Fig. 7). The 50\% decorrelation distance of the pairwise correlation between GSAs were-was estimated as $948 \mathrm{~km}(845-1075 \mathrm{~km}, 95 \% \mathrm{CI})$ for anchovy and $843 \mathrm{~km}(732-1031 \mathrm{~km}, 95 \% \mathrm{CI})$ for sardine. However, some harbors separated by small distance could also displayed a low Pearson correlation coefficient (e.g. between Split and Chioggia for anchovy, respectively on the eastern and western coast of the Northern Adriatic Sea, Table 2.), indicating that occasional strong local variability in fish body condition also occurred between neighborhoods harbors, mainly for anchovy (Table 2.). 

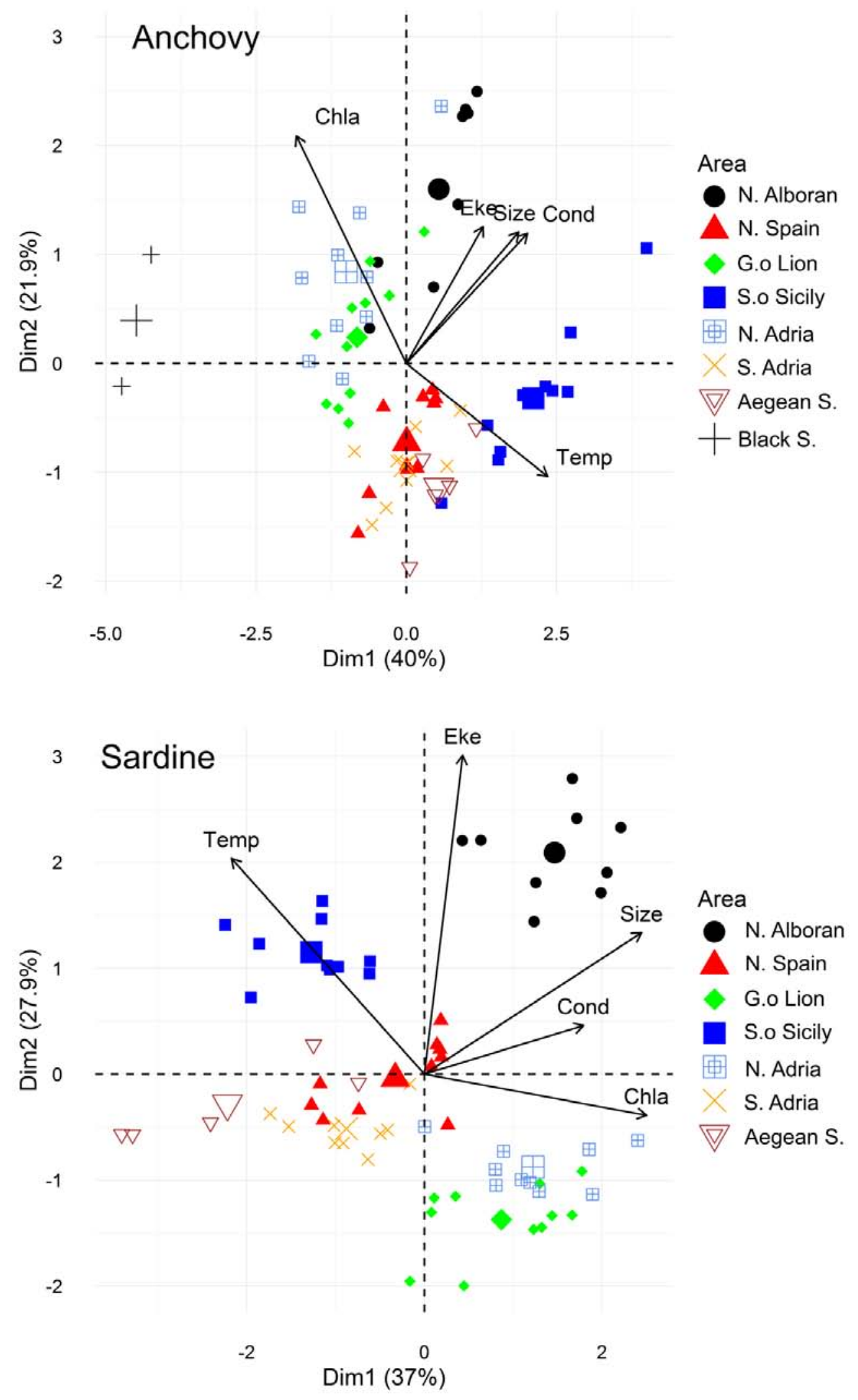

Figure 6. Principal component analysis for (a) anchovy and (b) sardine-from using MEDIAS data, showing the relative importance of two fish biological parameters and three environmental factors of 8 different Mediterranean areas. The variance explained by each axis is indicated between brackets. Larger symbols reflect the barycenter of each area. Sardine for not inhabit the Black Sea, so this area was excluded from this analysis. 

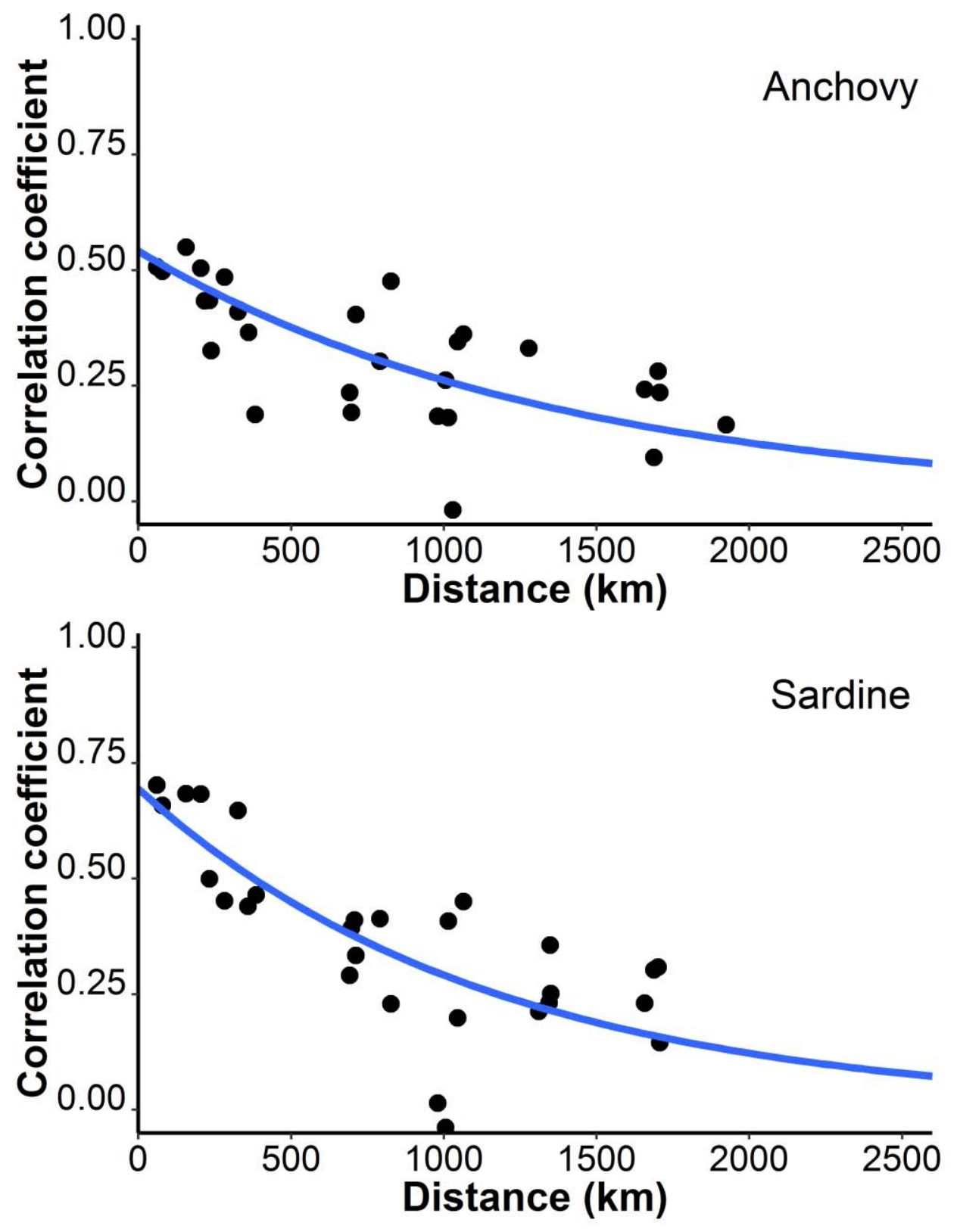

Figure 7. Exponential decline over distance of pairwise correlations between anchovy or sardine body condition time series from 9 different harbors ( 5 in the Adriatic Sea: Split, Ancona, San Benedetto, Chioggia and Porto Garibaldi; 2 in the Northern Alboran Sea: Màlaga and Torrevieja, 1 in the Northern Spain area: Tarragona and 1 in the Gulf of Lions: Sète). 


\section{Discussion}

Anchovy and sardine exhibited a decreasing trend in body condition in most of the studied areas, i.e. four or five over six for anchovy and sardine, respectively. None of the studied species in the different Mediterranean areas displayed a long term increase thend in their body condition on the long term. The general decrease of the in small pelagic fish body condition is in agreement with other observations, describing such as a decreasing biomass of several stocks and weakened biological state for both species at the Mediterranean scale (Tsikliras et al., 2015; Vasilakopoulos et al., 2014; Vilibić et al., 2016). This is particularly clear for anchoy in some areas, such as the NW Mediterranean, where small sized less fecund individuals presenting lower fecundity (McBride et al., 2015) in a low health status (i.e. lower lipid content and higher intensity of certain parasites, Ferrer-Maza et al., 2016a, Van Beveren et al., 2016b) are dominant in the population.

Additionally to this general statement of decreasing fish condition, sardine body condition dropped synchronously in 2006 and 2007 in four areas, indicating potential broad-scale causes affecting nearly simultaneously the majority of studied stocks. The range of breakpoint years was more spread between areas for anchovy than sardine, as body condition dropped between 2004 and 2009. Further, maximum size, a relevant parameter to monitor population changes due to its impact on survival, growth and reproduction of individuals (e.g. larger fish are more fecund, McBride et al., 2015) also decreased concomitantly with fish body condition for both species in most areas. A general and rapid change affecting the entire Mediterranean Sea could thus be involved to explain the synchrony observed. Small pelagic fish body condition is known to be primarily affected by food availability, especially the zooplanktonic compartment which constitutes the bulk of small pelagic fish preys (Basilone et al., 2006; Brosset et al., 2015b). Lower quality and/or quantity in food resources may have negatively affected fish growth, lowering overall mean and maximum fish size. and c Changes in the zooplanktonic eempartment-community have been observed in different parts of the Mediterranean. For example, a shift towards smaller zooplankton biomass in 2003 in the Adriatic (Mozetič et al., 2012) or a change towards smaller plankton species in the Northern Spain area since 2000's related to increasing temperature and stratification (Calvo et al., 2011) were described. Few data are available in other areas, even if similar changes are suspected to have occurred in for example the Gulf of Lions (Auger et al., 2014). Although chl- $a$ is a proxy of primary production and is available thanks to satellite data, longer precise plankton time series (with at least main functional groups) are required to exactly link food availability to fish body condition and size fluctuations to precise changes in the quantity and quality of plankton.

Even if a general decrease in body condition was visible for both species, this pattern could not be explained with global environmental factors, such as climatic indices which did not display synchronous breakpoints with fish body condition. Furthermore, the importance of regional factors was highlighted by both the results of the PCAs and the analyses of spatial covariability. For the latter, a $50 \%$ decorrelation distance of about $900 \mathrm{kms}$ (i.e. 950 and $850 \mathrm{kms}$ for anchovy and sardine, respectively) was detected. In other words, small pelagic fish body condition may not vary in synchrony at the Mediterranean scale, but rather at the scale of sub-regions. of about 750 kilometers. This is also confirmed by Pearson correlation coefficients value, which alloweding identifying elusters of harbors coming from the same region. Because of the small number of time series and the resulting uncertainties of the underlying fish condition autocorrelation functions, we can only make a preliminary and rough comparison with correlograms for other species. Nevertheless, when we compare those correlograms to the spatial autocorrelation of zooplankton (biomass and abundance or even phenology), which represents the main prey of small pelagic fish and greatly 
influence their body condition (Brosset et al., 2015b), similar values up to 950 kilometers were found (Batchelder et al., 2012; Mackas et al., 2012). These findings are supported by other related works: for For example, Mackas et al., (2012) computed a 50\% decorrelation distance around $1000 \mathrm{~km}$ in the Mediterranean and NE Atlantic zooplankton phenology time series, while Batchelder et al., (2012) found it decorrelation to occur between 643 and $673 \mathrm{~km}$ depending on the length of zooplankton abundance time series used, so some values in the vicinity of those found for anchovy and sardine in this study. This highlights the strong link between small pelagic fish and their prey, as well as the fact that no global coherence at Mediterranean seale might oceur for small pelagic fish body condition. The comparison of areas on an annual basis reflected marked environmental differences discriminating areas. This also highlighted a main effect of productivity on sardine body condition and Eke on anchovy body condition. Areas were similarly segregated for both species, with Strait of Sicily and Aegean Sea (Eastern areas) gathered, while the two other constant groups appeared along a latitudinat gradient with the Southern Adriatic plus the Northern Spain area grouped together and the Gulf of Lions plus the Northern Adriatic forming the other group. As mentioned above, this strong regionalization of the environment in the Mediterranean Sea was also confirmed by the results of the PCAs. For both species, areas were mostly marked by spatial (inter-area) variability and were aggregated into three main groups: the eastern areas (the Strait of Sicily and the Aegean Sea), the northern areas (the Gulf of Lions and the Northern Adriatic) and the southern areas (the Southern Adriatic and the Northern Spain area). The Alboran Sea mainly stands apart, probably due to the strong influence of the Atlantic waters which are characterized by low deviations on the annual average values of biological parameters (Renault et al., 2012), and are richer in zooplankton biomass (Youssara and Gaudy, 2001), creating a relatively stable environment. This of distinct and well separated areas with similar environmental and fish parameters and previous results obtained on another temporal seale (monthly basis) reflecting the absence of coherence in fish body condition fluctuations at large seale in the Mediterranean due to the spatial heterogeneity. Areas were thus distinct in terms of demographic and environmental characteristics, a result in coherence with the scale of about $900 \mathrm{kms}$ displayed by covariability analyses. Although the Mediterranean Sea is strongly affected by large atmospheric transfers (Vargas-Yáñez et al., 2008; Martín et al., 2011), forceful influences are also attributable to more local factors, such as river runoff, which induce contrasted conditions at small temporal and spatial scales. As a consequence, more local drivers had to be investigated in order to better understand these fluctuations. For example, anchovy optimal habitat is usually seen to be related to high frontal activities and river inputs (Agostini and Bakun, 2002; Morais et al., 2012; Giannoulaki et al., 2013; Carpi et al., 2015), resulting in strong water masses mixing. The covariation between anchovy body condition and Eke observed in the PCA thus tended to confirmed that important mesoscale activity might create favorable biotic conditions for this species, which. This was already observed for anchovy in the Humboldt ecosystem (Bertrand et al., 2004).-River runoffs are known to potentially affect fish condition (Lloret et al., 2004), but because of a lack of appropriate measures to evaluate correctly river discharges in the different areas (i.e. when no major river is present), this parameter was not taken into account in the PCA but it will necessitate to be correctly incorporated in further spatial work. Sardine is known to prefer colder waters than anchovy (Palomera et al., 2007), explaining the opposition between its body condition and high temperature. Chlorophyll $a$ plays an important role on sardine body condition which may be explained by the fact that sardine also feeds on diatoms additionally to zooplankton when anchovy do not (Costalago and Palomera, 2014; Nikolioudakis et al., 2014) even if phytoplankton consumption remains minor. Finally, Atlantic water inputs are characterized by low deviations on the annuat average values of biological parameters (Renault et al., 2012), and are richer in zooplankton biomass (Youssara and Gaudy, 2001), creating a relatively stable environment. This might explain why the North Alboran Sea stands apart both in the PCA analyses and in terms of trends. Yet, despite the 
important covariation of environmental parameters with body condition and size of sardine and anchovy to explain spatial differences, synchronies in the breakpoints of fish body condition and other environmental factors considered were only rare in most of the areas. This might come from the importance of even more local factors (e.g. small rivers runoff, local upwellings) or the lack of data on small pelagic fish main preys (e.g. zooplankton species). Another explanation could be the delay and/or the complexity of the interactions between environmental variations and fish body condition responses.

The higher level of detection of breakpoints and environmental relationships in the Adriatic (more specifically river runoff, chlorophyll $a$ and SST for that area) might be related to its geographic situation. The Adriatic Sea (especially in the northern part) is a quasi-closed basin in comparison to more open areas (e.g. the Gulf of Lions or the Catalan Sea), which might reinforce the effects of local environmental factors. Further, the length of the fisheries monthly time series in the Adriatic (37 years) also enabled us to study long-term patterns in terms of periodicity. Small pelagic fish body condition is known to display a clear annual pattern together with a strong low frequency signal in the major upwelling regions of the world-(Lluch-Belda et al., 1989; Chavez et al., 2003; Lindegren et al., 2013). In this study we found that body condition in the Adriatic had a strong annual cycle and a less pronounced periodic cycle of 6.7 years, which could be related to regime alternations between warm and cold environmental regimes as in strong upwelling regions condition, mainly as a result of ehanges in SST and productivity. Even if The importance of local factors, in this quasi-closed basin may explain difficulties to see low frequency cycles. In addition, it's seasonality of the annual cycle also changed in both species. The condition's peak moved earlier over the years, modifying fish energy storage during the year as already underlined by Zorica et al., (2013). This may results from environmental changes in the Adriatic Sea between 1975 and 2012 (as underlined for the period 1997 to 2015 in the breakpoint analysis). Indeed,Phytoplankton production mostly depends on nutrients, light and temperature. As warmed waters promoted earlier phytoplankton development while and stronger water stratification led to a reduced second peak of primary production (Edwards and Richardson, 2004), primary production and zooplankton bloomed earlier. These two phenomena resulted in an earlier bloom of primary production and consequently secondary producers (zooplankton) and This may explain why the peak in fish energy storage moved shifted toward previous earlier months along years for both species. The timing of the peak in anchovy peak of body condition, even if shifted earlier (from October/November to June) still occurs during the reproductive period (late spring and summer). Thus, anchovy can allocate large stores reserves to reproduction, a phase really highly demanding on energy (Williams, 1966) and still survive to the following winter. On the contrary, sardine has to store a maximum of energy before winter reproduction when few resources are available. However, while body condition peaked (September/November) was just before reproduction until the mid 90's (September/November) and, it is now peaks in July,-se longer before reproduction takes place, preventing sardine to reach the reproductive period with its highest maximal fat storage. This difference can make the sardine population more sensitive to current environmental changes in the Adriatic Sea, as has already been observed in the Gulf of Lions (Brosset et al., 2016b), where sardine has less energy to both overwinter and reproduce. by lowering the energy quantity available to accomplish both reproduction and Longer time series on a monthly basis will be required to provide conclusions for other areas, and see if the Adriatic Sea situation is unique or if the body condition's annual peak has moved earlier in all areas. 
Apart from environmental factors, fishing can also affect fish condition and size, which is important to stress as most of the stocks are overexploited in the Mediterranean (GFCM, 2014). Fishing can impact fish condition through overfishing on their main preys, as demonstrated for demersal species (Hiddink et al., 2005). As small pelagic fish depend on planktonic preys, which are not exploited, such a process remains however very unlikely. A more likely process relies on the catchability that is often size and condition-dependent. Indeed, fisheries-induced selection is known to magnify shifts toward young, small and more quickly maturing individuals in targeted populations (Devine et al., 2012; Audzijonyte et al., 2013a; Mollet et al., 2016, Kuparinen et al., 2016), but difficulties remain in distinguishing phenotypical responses from true evolutionary changes. Phenotypic plasticity deals with the adaptive response of an organism faced with fishing pressure and/or changing environment. As fishing can reduced fish density, resulting in a decrease in food and space competition, faster growth and earlier maturation can occur. Alternatively, faster growth and earlier maturation can be a consequence of changing genetic composition of population for certain trait values, fishing also determines evolutionary dynamic. Several studies have shown that these phenotypic changes might be directly induced by fishing and/or result from evolutionary responses to fisheries-induced selection. Thus, additionally to the effect on growth of the current poor body condition, the decreasing trend in body size may be also due to an evolutionary response to intensive size selective fishing in overexploited Mediterranean areas (see also Conover and Munch, 2002). This appears unlikely for the Gulf of Lions because of the asynchrony between fishing pressure and the decline in size and condition and the historical low harvest rates (van Beveren et al. 2016). However, major changes observed in other areas might be explained by the combined effect of exploitation and environmental changes, especially in areas where anchovy and sardine were clearly overexploited, such as the Adriatic Sea (FAO, 2014). Unfortunately, no proper long-term information on fishing effort directed to each stock was available, preventing us to quantify ecological feedbacks of such life-history changes. Indeed, effort monitoring programs differ between countries and Mediterranean fisheries are often opportunistic (multispecific in some areas), making it impossible to quantify precisely fishing effort on all these stocks.

Complementary data to extend the length of the time series in other areas are needed to investigate deeply long term periodicity patterns in small pelagic fish body condition at the Mediterranean scale. Low frequency signals (interdecadal, decadal, interannual) have been found in other marine areas (Lluch-Belda et al., 1989; Chavez et al., 2003; Lindegren et al., 2013), and even if small pelagic fish body condition mainly display seasonal cycle, low frequency signal mntil 6 years were also seen in the Adriatic.

Based on scientific surveys and fisheries data linked to environmental data, this study evaluates for the first time the temporal and spatial variability in body condition of the two main small pelagic fish at the Mediterranean scale. The ebtained results highlighted a general decrease in fish body condition and maximum size, probably related to changes in planktonic quantity and/or quality. The forecasted trend for the near future is that of an increase in mean Mediterranean SST, sea surface salinity and water stratification (Vargas-Yáñez et al., 2010; Adloff et al., 2015), favoring lower size classes of plankton (Herrmann et al., 2013). In such conditions, small pelagic fish condition may stay really remain poor or even continue to decline as smaller plankton has lower energetic values will induce a strengthening of reduced fish body condition values due to its lower energetic values (Vijverberg and Frank, 1976; Zarubin et al., 2014). Anchovy body condition was mainly linked to Eke, which may also decrease due to stronger and longer water stratifieation periods during summer. As well as for sardine, this means that anchory body condition is thus expected to stay low or decrease during future 
deades. Further, due to a lack of reliable data, this analysis did not take into account the exploitation pressure, that we know is high in several stocks and that might well explain part of the decline in some areas. This decreasing trend in the condition of small pelagic fish may have long-lasting negative effects on the Mediterranean fisheries through an effect on life-history traits such as growth, reproduction or natural mortality hampering stock productivity and hence future fisheries yield, as well as on other ecosystem components such as predators preying on small pelagic fish (e.g. Wanless et al., 2005). Moreover, if condition of small pelagic fish is would be decreasing further, it may negatively affect the condition status of other ecosystem components such as predators preying on these small pelagic fish (e.g. birds Wanless et al., 2005). Considering fish population body condition through scientific surveys and fisheries landings samplings should now be gathered with environmental regular monitoring (including planktonic sampling) and considered in order to implement and provide effective and efficient management plans in the Mediterranean Sea.

Anchovy body condition was shown to be dependent for on Eke while sardine body condition was rather linked to chlorophyll $a$, underlining different responses to environmental factors for both species. Furthermore, these results provided information in the framework of an ecosystem approach to fisheries. All these This information derived from scientific acoustic surveys and fisheries landings samplings should be considered in a management perspective of small pelagic Mediterranean stocks based on fish and environmental regular monitoring in order to implement and provide effective and efficient management plans in the Mediterranean Sea considering fish population body condition.

\section{Acknowledgements}

The authors are grateful to the captain and the crew of Research Vessels, as well as all the scientists onboard for their assistance during MEDIAS surveys. The authors acknowledge Dr. Alberto Santojanni from CNR-ISMAR Ancona for the Italian Adriatic fisheries data from 2008 to 2013 and the 'Servizio Idrometerologico Regione Emilia Romagna' for Po river data. The authors express their thanks to all people who accepted to share data and to the GFCM WGSASP working group and especially Miguel Bernal. PB acknowledges doctoral fellowship support from the French Ministère de l'Education Nationale, de la Recherche et de la Technologie.

\section{References}

Adams, S. M. 1999. Ecological Role of Lipids in the Health and Success of Fish Populations. In Lipids in Freshwater Ecosystems, pp. 132-160. Ed. by M. T. Arts and B. C. Wainman. Springer New York.

Adloff, F., Somot, S., Sevault, F., Jordà, G., Aznar, R., Déqué, M., Herrmann, M., et al. 2015. Mediterranean Sea response to climate change in an ensemble of twenty first century scenarios. Climate Dynamics, 45: 2775-2802.

Agostini, V. N., and Bakun, A. 2002. 'Ocean triads' in the Mediterranean Sea: physical mechanisms potentially structuring reproductive habitat suitability (with example application to European anchovy, Engraulis encrasicolus). Fisheries Oceanography, 11: 129-142.

Artioli, Y., Friedrich, J., Gilbert, A. J., McQuatters-Gollop, A., Mee, L. D., Vermaat, J. E., Wulff, F., et al. 2008. Nutrient budgets for European seas: A measure of the effectiveness of nutrient reduction policies. Marine Pollution Bulletin, 56: 1609-1617.

Audzijonyte, A., Kuparinen, A., and Fulton, E. A. 2013. How fast is fisheries-induced evolution? Quantitative analysis of modelling and empirical studies. Evolutionary applications, 6: 585595. 
Auger, P. A., Ulses, C., Estournel, C., Stemmann, L., Somot, S., and Diaz, F. 2014. Interannual control of plankton communities by deep winter mixing and prey/predator interactions in the NW Mediterranean: Results from a 30-year 3D modeling study. Progress in Oceanography, 124: 12-27.

Bănaru, D., Mellon-Duval, C., Roos, D., Bigot, J.-L., Souplet, A., Jadaud, A., Beaubrun, P., et al. 2013. Trophic structure in the Gulf of Lions marine ecosystem (north-western Mediterranean Sea) and fishing impacts. Journal of Marine Systems, 111-112: 45-68.

Basilone, G., Guisande, C., Patti, B., Mazzola, S., Cuttitta, A., Bonanno, A., Vergara, A. R., et al. 2006. Effect of habitat conditions on reproduction of the European anchovy (Engraulis encrasicolus) in the Strait of Sicily. Fisheries Oceanography, 15: 271-280.

Basilone, G., Bonanno, A., Patti, B., Mazzola, S., Barra, M., Cuttitta, A., and McBride, R. 2013. Spawning site selection by European anchovy (Engraulis encrasicolus) in relation to oceanographic conditions in the Strait of Sicily. Fisheries Oceanography, 22: 309-323.

Batchelder, H. P., Mackas, D. L., and O'Brien, T. D. 2012. Spatial-temporal scales of synchrony in marine zooplankton biomass and abundance patterns: A world-wide comparison. Progress in Oceanography, 97-100: 15-30.

Baumgartner, T., Soutar, A., and Riedel, W. 1992. Natural time scales of variability in coastal pelagic fish populations of the California Current over the past 1500 years: Response to global climate change and biological interaction. California Sea Grant Rep. for, 1995: 31-37.

Bertrand, A., Segura, M., Gutiérrez, M., and Vásquez, L. 2004. From small-scale habitat loopholes to decadal cycles: a habitat-based hypothesis explaining fluctuation in pelagic fish populations off Peru. Fish and Fisheries, 5: 296-316.

Bethoux, J. P., Gentili, B., Raunet, J., and Tailliez, D. 1990. Warming trend in the western Mediterranean deep water. Nature, 347: 660-662.

Bolger, T., and Connolly, P. L. 1989. The selection of suitable indices for the measurement and analysis of fish condition. Journal of Fish Biology, 34: 171-182.

Bonanno, A., Giannoulaki, M., Barra, M., Basilone, G., Machias, A., Genovese, S., Goncharov, S., et al. 2014. Habitat Selection Response of Small Pelagic Fish in Different Environments. Two Examples from the Oligotrophic Mediterranean Sea. PLoS ONE, 9: e101498.

Brosset, P., Fromentin, J.-M., Ménard, F., Pernet, F., Bourdeix, J.-H., Bigot, J.-L., Van Beveren, E., et al. 2015a. Measurement and analysis of small pelagic fish condition: A suitable method for rapid evaluation in the field. Journal of Experimental Marine Biology and Ecology, 462: 90-97.

Brosset, P., Menard, F., Fromentin, J., Bonhommeau, S., Ulses, C., Bourdeix, J., Bigot, J., et al. 2015b. Influence of environmental variability and age on the body condition of small pelagic fish in the Gulf of Lions. Marine Ecology Progress Series, 529: 219-231.

Brosset, P., Lloret, J., Munoz, M., Fauvel, C., Van Beveren, E., Marques, V., Fromentin, J.-M., et al. 2016a. Body reserves mediate trade-offs between life-history traits: new insights from small pelagic fish reproduction. Royal Society Open Science, 3.

Brosset, P., Le Bourg, B., Costalago, D., Bănaru, D., Van Beveren, E., Bourdeix, J., Fromentin, J., et al. 2016b. Linking small pelagic dietary shifts and ecosystem changes in the Gulf of Lions. Marine Ecology Progress Series. http://www.int-res.com/prepress/m11796.html (Accessed 13 June 2016).

Calvo, E., Simó, R., Coma, R., Ribes, M., Pascual, J., Sabatés, A., Gili, J., et al. 2011. Effects of climate change on Mediterranean marine ecosystems: the case of the Catalan Sea. Climate Research, 50: 1-29.

Carpi, P., Martinelli, M., Belardinelli, A., Russo, A., Arneri, E., Coluccelli, A., and Santojanni, A. 2015. Coupling an oceanographic model to a Fishery Observing System through mixed models: the importance of fronts for anchovy in the Adriatic Sea. Fisheries Oceanography, 24: 521-532.

Chavez, F. P., Ryan, J., Lluch-Cota, S. E., and C, M. N. 2003. From Anchovies to Sardines and Back: Multidecadal Change in the Pacific Ocean. Science, 299: 217-221.

Colebrook, J. M. 1978. Continuous plankton records-zooplankton and environment, northeast Atlantic and North-Sea, 1948-1975. Oceanologica Acta, 1: 9-23. 
Coll, M., and Libralato, S. 2012. Contributions of food web modelling to the ecosystem approach to marine resource management in the Mediterranean Sea. Fish and Fisheries, 13: 60-88.

Conover, D. O., and Munch, S. B. 2002. Sustaining Fisheries Yields Over Evolutionary Time Scales. Science, 297: 94-96.

Conte, M., Guiffrida, A., and Tedesco, S. 1989. The Mediterranean Oscillation: Impact on Precipitation and Hydrology in Italy Climate Water.

Costalago, D., Palomera, I., and Tirelli, V. 2014. Seasonal comparison of the diets of juvenile European anchovy Engraulis encrasicolus and sardine Sardina pilchardus in the Gulf of Lions. Journal of Sea Research, 89: 64-72.

Costalago, D., and Palomera, I. 2014. Feeding of European pilchard (Sardina pilchardus) in the northwestern Mediterranean: from late larvae to adults. Scientia Marina, 78: 41-54.

Cury, P., Bakun, A., Crawford, R. J. M., Jarre, A., Quiñones, R. A., Shannon, L. J., and Verheye, H. M. 2000. Small pelagics in upwelling systems: patterns of interaction and structural changes in 'wasp-waist' ecosystems. ICES Journal of Marine Science: Journal du Conseil, 57: 603-618.

Cushing, D. H., and Dickson, R. R. 1976. The biological response in the sea to climatic changes. Advances in Marine Biology, 14: 1-122.

Darnaude, A. M., Salen-Picard, C., Polunin, N. V. C., and Harmelin-Vivien, M. L. 2004. Trophodynamic linkage between river runoff and coastal fishery yield elucidated by stable isotope data in the Gulf of Lions (NW Mediterranean). Oecologia, 138: 325-332.

Devine, J. A., Wright, P. J., Pardoe, H. E., and Heino, M. 2012. Comparing rates of contemporary evolution in life-history traits for exploited fish stocks. Canadian Journal of Fisheries and Aquatic Sciences, 69: 1105-1120.

Drinkwater, K. F., Beaugrand, G., Kaeriyama, M., Kim, S., Ottersen, G., Perry, R. I., Pörtner, H.-O., et al. 2010. On the processes linking climate to ecosystem changes. Journal of Marine Systems, 79: 374-388.

Edwards, M., and Richardson, A. J. 2004. Impact of climate change on marine pelagic phenology and trophic mismatch. Nature, 430: 881-884.

FAO,. 2014. The state of world Fisheries and Aquaculture (SOFIA) 2014. Rome: FAO Fisheries and Aquaculture Department.

Ferrer-Maza, D., Lloret, J., Muñoz, M., Vila, S., Faliex, B., and Sasal, P. 2016a. Links between parasitism, energy reserves and fecundity of European anchovy, Engraulis encrasicolus, in the northwestern Mediterranean Sea. Conservation Physiology (in press).

Ferrer-Maza, D., Lloret, J., Muñoz, M., Faliex, E., Vila, S., and Sasal, P. 2016b. Links between parasitism, energy reserves and fecundity of European anchovy, Engraulis encrasicolus, in the northwestern Mediterranean Sea. Conservation Physiology, 4: cov069.

Garcia, A., Cortes, D., and Ramirez, T. 1998. Daily larval growth and RNA and DNA content of the NW Mediterranean anchovy Engraulis encrasicolus and their relations to the environment. Marine Ecology Progress Series, 166: 237-245.

GFCM. 2012. Report of the working group on stock assessment of small pelagic species, p 258.

GFCM. 2014. Report of the working group on stock assessment of small pelagic species, p39.

Giannoulaki, M., Iglesias, M., Tugores, M. P., Bonanno, A., Patti, B., De Felice, A., Leonori, I., et al. 2013. Characterizing the potential habitat of European anchovy Engraulis encrasicolus in the Mediterranean Sea, at different life stages. Fisheries Oceanography, 22: 69-89.

Giorgi, F. 2006. Climate change hot-spots. Geophysical Research Letters, 33: L08707.

Gucu, A. C., Inanmaz, Ö. E., Ok, M., and Sakinan, S. 2016. Recent changes in the spawning grounds of Black Sea anchovy, Engraulis encrasicolus. Fisheries Oceanography, 25: 67-84.

Halpern, B. S., Walbridge, S., Selkoe, K. A., Kappel, C. V., Micheli, F., D’Agrosa, C., Bruno, J. F., et al. 2008. A Global Map of Human Impact on Marine Ecosystems. Science, 319: 948-952.

Herrmann, M., Diaz, F., Estournel, C., Marsaleix, P., and Ulses, C. 2013. Impact of atmospheric and oceanic interannual variability on the Northwestern Mediterranean Sea pelagic planktonic ecosystem and associated carbon cycle. Journal of Geophysical Research: Oceans, 118: 57925813. 
Hiddink, J. G., Jennings, S., and Kaiser, M. J. 2005. Do haddock select habitats to maximize condition? Journal of fish biology, 67: 111-124.

Hoegh-Guldberg, O., and Bruno, J. F. 2010. The Impact of Climate Change on the World's Marine Ecosystems. Science, 328: 1523-1528.

Hurrell, J. W. 1995. Decadal Trends in the North Atlantic Oscillation: Regional Temperatures and Precipitation. Science, 269: 676-679.

Hurrell, J. W., and Loon, H. V. 1997. Decadal Variations in Climate Associated with the North Atlantic Oscillation. In Climatic Change at High Elevation Sites, pp. 69-94. Ed. by H. F. Diaz, M. Beniston, and R. S. Bradley. Springer Netherlands. http://link.springer.com/chapter/10.1007/978-94-015-8905-5_4 (Accessed 13 September 2016).

Ibanez, F., and Dauvin, J.-C. 1988. Long-term changes(1977 to 1987) in a muddy fine sand Abra albaMelinna palmata community from the western English Channel: Multivariate time-series analysis. Marine ecology progress series. Oldendorf, 49: 65-81.

Jakob, E. M., Marshall, S. D., and Uetz, G. W. 1996. Estimating Fitness: A Comparison of Body Condition Indices. Oikos, 77: 61-67.

Jørgensen, T. 1992. Long-term changes in growth of North-east Arctic cod (Gadus morhua) and some environmental influences. ICES Journal of Marine Science: Journal du Conseil, 49: 263-278.

Kerr, R. A. 2000. A North Atlantic Climate Pacemaker for the Centuries. Science, 288: 1984-1985.

Kuparinen, A., Boit, A., Valdovinos, F. S., Lassaux, H., and Martinez, N. D. 2016. Fishing-induced lifehistory changes degrade and destabilize harvested ecosystems. Scientific Reports, 6. http://www.ncbi.nlm.nih.gov/pmc/articles/PMC4768105/ (Accessed 30 September 2016).

Le Bourg, B., Bănaru, D., Saraux, C., Nowaczyk, A., Le Luherne, E., Jadaud, A., Bigot, J. L., et al. 2015. Trophic niche overlap of sprat and commercial small pelagic teleosts in the Gulf of Lions (NW Mediterranean Sea). Journal of Sea Research, 103: 138-146.

Le Cren, E. D. 1951. The Length-Weight Relationship and Seasonal Cycle in Gonad Weight and Condition in the Perch (Perca fluviatilis). Journal of Animal Ecology, 20: 201-219.

Lindegren, M., Checkley, D. M., Rouyer, T., MacCall, A. D., and Stenseth, N. C. 2013. Climate, fishing, and fluctuations of sardine and anchovy in the California Current. Proceedings of the National Academy of Sciences, 110: 13672-13677.

Lleonart, J., and Maynou, F. 2003. Fish stock assessments in the Mediterranean: state of the art. Scientia Marina, 67: 37-49.

Lloret, J., Palomera, I., Salat, J., and Sole, I. 2004. Impact of freshwater input and wind on landings of anchovy (Engraulis encrasicolus) and sardine (Sardina pilchardus) in shelf waters surrounding the Ebre (Ebro) River delta (north-western Mediterranean). Fisheries Oceanography, 13: 102-110.

Lloret, J., Faliex, E., Shulman, G. E., Raga, J.-A., Sasal, P., Muñoz, M., Casadevall, M., et al. 2012. Fish Health and Fisheries, Implications for Stock Assessment and Management: The Mediterranean Example. Reviews in Fisheries Science, 20: 165-180.

Lloret, J., Shulman, G., and Love, R. M. 2014. Condition and Health Indicators of Exploited Marine Fishes. John Wiley \& Sons. 263 pp.

Lloret, J., Sabatés, A., Muñoz, M., Demestre, M., Solé, I., Font, T., Casadevall, M., et al. 2015. How a multidisciplinary approach involving ethnoecology, biology and fisheries can help explain the spatio-temporal changes in marine fish abundance resulting from climate change. Global Ecology and Biogeography, 24: 448-461.

Lluch-Belda, D., Crawford, R. J. M., Kawasaki, T., MacCall, A. D., Parrish, R. H., Schwartzlose, R. A., and Smith, P. E. 1989. World-wide fluctuations of sardine and anchovy stocks: the regime problem. South African Journal of Marine Science, 8: 195-205.

Macías, D., Bruno, M., Echevarría, F., Vázquez, A., and García, C. M. 2008. Meteorologically-induced mesoscale variability of the North-western Alboran Sea (southern Spain) and related biological patterns. Estuarine, Coastal and Shelf Science, 78: 250-266. 
Mackas, D. L., Greve, W., Edwards, M., Chiba, S., Tadokoro, K., Eloire, D., Mazzocchi, M. G., et al. 2012. Changing zooplankton seasonality in a changing ocean: Comparing time series of zooplankton phenology. Progress in Oceanography, 97: 31-62.

Mantel, N. 1967. The Detection of Disease Clustering and a Generalized Regression Approach. Cancer Research, 27: 209-220.

Martín, P., Sabatés, A., Lloret, J., and Martin-Vide, J. 2011. Climate modulation of fish populations: the role of the Western Mediterranean Oscillation (WeMO) in sardine (Sardina pilchardus) and anchovy (Engraulis encrasicolus) production in the north-western Mediterranean. Climatic Change, 110: 925-939.

Martin-Vide, J., and Lopez-Bustins, J.-A. 2006. The Western Mediterranean Oscillation and rainfall in the Iberian Peninsula. International Journal of Climatology, 26: 1455-1475.

Maynou, F., Sabatés, A., and Salat, J. 2014. Clues from the recent past to assess recruitment of Mediterranean small pelagic fishes under sea warming scenarios. Climatic Change, 126: 175188.

McBride, R. S., Somarakis, S., Fitzhugh, G. R., Albert, A., Yaragina, N. A., Wuenschel, M. J., AlonsoFernández, A., et al. 2015. Energy acquisition and allocation to egg production in relation to fish reproductive strategies. Fish and Fisheries, 16: 23-57.

McPherson, L. R., Slotte, A., Kvamme, C., Meier, S., and Marshall, C. T. 2011. Inconsistencies in measurement of fish condition: a comparison of four indices of fat reserves for Atlantic herring (Clupea harengus). ICES Journal of Marine Science: Journal du Conseil, 68: 52-60.

Millar, J. S., and Hickling, G. J. 1990. Fasting Endurance and the Evolution of Mammalian Body Size. Functional Ecology, 4: 5-12.

Millot, C. 1990. The Gulf of Lions' hydrodynamics. Continental Shelf Research, 10: 885-894.

Mollet, F. M., Dieckmann, U., and Rijnsdorp, A. D. 2016. Reconstructing the effects of fishing on lifehistory evolution in North Sea plaice Pleuronectes platessa. Marine Ecology Progress Series, 542: 195-208.

Morais, P., Martins, F., Chícharo, M. A., Lopes, J., and Chícharo, L. 2012. Merging anchovy eggs abundance into a hydrodynamic model as an assessment tool for estuarine ecohydrological management. River Research and Applications, 28: 160-176.

Mozetič, P., Francé, J., Kogovšek, T., Talaber, I., and Malej, A. 2012. Plankton trends and community changes in a coastal sea (northern Adriatic): Bottom-up vs. top-down control in relation to environmental drivers. Estuarine, Coastal and Shelf Science, 115: 138-148.

Nikolioudakis, N., Isari, S., and Somarakis, S. 2014. Trophodynamics of anchovy in a non-upwelling system: direct comparison with sardine. Marine Ecology Progress Series, 500: 215-229.

Ospina-Alvarez, A., Parada, C., and Palomera, I. 2012. Vertical migration effects on the dispersion and recruitment of European anchovy larvae: From spawning to nursery areas. Ecological Modelling, 231: 65-79.

Özsoy, E., and Ünlüata, Ü. 1997. Oceanography of the Black Sea: A review of some recent results. Earth-Science Reviews, 42: 231-272.

Palomera, I., Olivar, M. P., Salat, J., Sabatés, A., Coll, M., García, A., and Morales-Nin, B. 2007. Small pelagic fish in the NW Mediterranean Sea: An ecological review. Progress in Oceanography, 74: 377-396.

Peck, M. A., Reglero, P., Takahashi, M., and Catalán, I. A. 2013. Life cycle ecophysiology of small pelagic fish and climate-driven changes in populations. Progress in Oceanography, 116: 220245.

Pörtner, H. O., and Knust, R. 2007. Climate Change Affects Marine Fishes Through the Oxygen Limitation of Thermal Tolerance. Science, 315: 95-97.

Pyper, B. J., and Peterman, R. M. 1998. Comparison of methods to account for autocorrelation in correlation analyses of fish data. Canadian Journal of Fisheries and Aquatic Sciences, 55: 2127-2140. 
Rätz, H.-J., and Lloret, J. 2003. Variation in fish condition between Atlantic cod (Gadus morhua) stocks, the effect on their productivity and management implications. Fisheries Research, 60: 369-380.

Renault, L., Oguz, T., Pascual, A., Vizoso, G., and Tintoré, J. 2012. Surface circulation in the Alborán Sea (western Mediterranean) inferred from remotely sensed data. Journal of Geophysical Research: Oceans, 117.

Rouyer, T., Fromentin, J., Stenseth, N. C., and Cazelles, B. 2008. Analysing multiple time series and extending significance testing in wavelet analysis. Marine Ecology Progress Series, 359: 1123.

Russo, A., and Artegiani, A. 1996. Adriatic sea hydrography. Scientia Marina, 60: 33-43.

Schulte-Hostedde, A. I., Millar, J. S., and Hickling, G. J. 2001. Evaluating body condition in small mammals. Canadian Journal of Zoology, 79: 1021-1029.

Schulte-Hostedde, A. I., Zinner, B., Millar, J. S., and Hickling, G. J. 2005. RESTITUTION OF MASS-SIZE RESIDUALS: VALIDATING BODY CONDITION INDICES. Ecology, 86: 155-163.

Stevenson, R. D., and Woods, W. A. 2006. Condition indices for conservation: new uses for evolving tools. Integrative and Comparative Biology, 46: 1169-1190.

Theocharis, A. 2008. Do we expect significant changes in the Thermohaline Circulation in the Mediterranean in relation to the observed surface layers warming. Climate warming and related changes in Mediterranean marine biota,: 25-30.

Tsikliras, A. C., Dinouli, A., Tsiros, V.-Z., and Tsalkou, E. 2015. The Mediterranean and Black Sea Fisheries at Risk from Overexploitation. PLOS ONE, 10: e0121188.

Van Beveren, E., Bonhommeau, S., Fromentin, J.-M., Bigot, J.-L., Bourdeix, J.-H., Brosset, P., Roos, D., et al. 2014. Rapid changes in growth, condition, size and age of small pelagic fish in the Mediterranean. Marine Biology: 1-14.

Van Beveren, E., Fromentin, J.-M., Rouyer, T., Bonhommeau, S., Brosset, P., and Saraux, C. $2016 a$. The fisheries history of small pelagics in the Northern Mediterranean. ICES Journal of Marine Science: Journal du Conseil, 73: 1474-1484.

Van Beveren, E. V., Keck, N., Fromentin, J.-M., Laurence, S., Boulet, H., Labrut, S., Baud, M., et al. 2016b. Can pathogens alter the population dynamics of sardine in the NW Mediterranean? Marine Biology, 163: 240.

Vargas-Yáñez, M., Jesús García, M., Salat, J., García-Martínez, M. C., Pascual, J., and Moya, F. 2008. Warming trends and decadal variability in the Western Mediterranean shelf. Global and Planetary Change, 63: 177-184.

Vargas-Yáñez, M., Moya, F., García-Martínez, M. C., Tel, E., Zunino, P., Plaza, F., Salat, J., et al. 2010. Climate change in the Western Mediterranean Sea 1900-2008. Journal of Marine Systems, 82: 171-176.

Vasilakopoulos, P., Maravelias, C. D., and Tserpes, G. 2014. The Alarming Decline of Mediterranean Fish Stocks. Current Biology, 24: 1643-1648.

Vijverberg, J., and Frank, T. H. 1976. The chemical composition and energy contents of copepods and cladocerans in relation to their size. Freshwater Biology, 6: 333-345.

Vilibic, I., Kec, V. Č., Zorica, B., Šepic, J., Matijevic, S., and Dzoic, T. 2016. Hydrographic conditions driving sardine and anchovy populations in a land-locked sea. Mediterranean Marine Science: $1-2$.

Wanless, S., Harris, M. P., Redman, P., and Speakman, J. R. 2005. Low energy values of fish as a probable cause of a major seabird breeding failure in the North Sea. Marine Ecology Progress Series, 294: 8.

Williams, G. C. 1966. Natural selection, the costs of reproduction, and a refinement of Lack's principle. American naturalist: 687-690.

Wilson, A. J., and Nussey, D. H. 2010. What is individual quality? An evolutionary perspective. Trends in Ecology \& Evolution, 25: 207-214.

Youssara, F., and Gaudy, R. 2001. Variations of zooplankton in the frontal area of the Alboran sea (Mediterranean sea) in winter 1997. Oceanologica Acta, 24: 361-376. 
Zarubin, M., Farstey, V., Wold, A., Falk-Petersen, S., and Genin, A. 2014. Intraspecific Differences in Lipid Content of Calanoid Copepods across Fine-Scale Depth Ranges within the Photic Layer. PLOS ONE, 9: e92935.

Zavatarelli, M., Raicich, F., Bregant, D., Russo, A., and Artegiani, A. 1998. Climatological biogeochemical characteristics of the Adriatic Sea. Journal of Marine Systems, 18: 227-263.

Zeileis, A., Leisch, F., Hornik, K., Kleiber, C., and Hansen, B. 2013. strucchange: Testing, Monitoring, and Dating Structural Changes. http://cran.rproject.org/web/packages/strucchange/index.html.

Zorica, B., Vilibić, I., Keč, V. Č., and Šepić, J. 2013. Environmental conditions conducive to anchovy (Engraulis encrasicolus) spawning in the Adriatic Sea. Fisheries Oceanography, 22: 32-40. 
Table 1. Summary of all biological data used in this study by area.

\begin{tabular}{|c|c|c|c|c|c|}
\hline Area & Species & Time period & Data origin & Sampling month & $\begin{array}{l}\text { Number of } \\
\text { individuals }\end{array}$ \\
\hline \multirow{6}{*}{$\begin{array}{c}\text { GSA } 1 \\
\text { North Northern } \\
\text { Alboran Sea }\end{array}$} & \multirow{2}{*}{ Anchovy } & 2001-2009 & ECOMED & November-December & 666 \\
\hline & & $2009-2013$ & MEDIAS & June-July & 182 \\
\hline & Anchovy & $\begin{array}{l}1990-1992 \& \\
2003-2013\end{array}$ & Fisheries & All months & 12,126 \\
\hline & \multirow{2}{*}{ Sardine } & $2001-2009$ & ECOMED & November-December & 1,600 \\
\hline & & $2009-2013$ & MEDIAS & June-July & 742 \\
\hline & Sardine & $\begin{array}{c}1990-1996 \& \\
2003-2013 \\
\end{array}$ & Fisheries & All months & 21,539 \\
\hline \multirow{6}{*}{$\begin{array}{c}\text { GSA } 6 \\
\text { Northern Spain }\end{array}$} & \multirow{2}{*}{ Anchovy } & 1993-2009 & ECOMED & November-December & 6,726 \\
\hline & & $2009-2013$ & MEDIAS & June-July & 4,649 \\
\hline & Anchovy & 2004-2013 & Fisheries & All months & 7,049 \\
\hline & \multirow{2}{*}{ Sardine } & 1993-2009 & ECOMED & November-December & 6,316 \\
\hline & & $2009-2013$ & MEDIAS & June-July & 8,923 \\
\hline & Sardine & 2004-2013 & Fisheries & All months & 13,157 \\
\hline \multirow{4}{*}{$\begin{array}{c}\text { GSA } 7 \\
\text { Gulf of Lions }\end{array}$} & Anchovy & $1993-2015$ & MEDIAS & June-July & 8,525 \\
\hline & Anchovy & $2005-2016$ & Fisheries & All months & 12,037 \\
\hline & Sardine & $1993-2015$ & MEDIAS & June-July & 9,464 \\
\hline & Sardine & $\begin{array}{c}1971-1983 \& \\
2003-2016 \\
\end{array}$ & Fisheries & All months & 18,551 \\
\hline \multirow{2}{*}{$\begin{array}{l}\text { GSA } 15 \& 16 \\
\text { Strait of Sicily }\end{array}$} & Anchovy & $1998-2013$ & MEDIAS & June-August & 1,331 \\
\hline & Sardine & $1998-2013$ & MEDIAS & June-August & 1,572 \\
\hline \multirow{4}{*}{$\begin{array}{c}\text { GSA } 17 \\
\text { Northern Adriatic } \\
\text { Sea }\end{array}$} & Anchovy & 1998-2013 & MEDIAS & July-October & 14,137 \\
\hline & Anchovy & $1975-2012$ & Fisheries & All months & 50,826 \\
\hline & Sardine & $1998-2013$ & MEDIAS & July-October & 7,550 \\
\hline & Sardine & $1975-2012$ & Fisheries & All months & 27,164 \\
\hline \multirow{2}{*}{$\begin{array}{c}\text { GSA } 18 \\
\text { Southern Adriatic } \\
\text { Sea } \\
\end{array}$} & Anchovy & 1998-2013 & MEDIAS & June-September & 1,849 \\
\hline & Sardine & $1998-2013$ & MEDIAS & June-September & 1,046 \\
\hline \multirow{2}{*}{$\begin{array}{c}\text { GSA } 22 \\
\text { Aegean Sea }\end{array}$} & Anchovy & 2003-2008 & MEDIAS & June-July & 8,574 \\
\hline & Sardine & $2003-2008$ & MEDIAS & June-July & 2,484 \\
\hline $\begin{array}{c}\text { GSA } 29 \\
\text { Black Sea }\end{array}$ & Anchovy & 2011-2013 & MEDIAS & November-March & 3,678 \\
\hline
\end{tabular}


Table 2. Pairwise correlation (Pearson coefficient) between fish body condition time series from 9 different harbors. Orange data come from anchovy and blue data from sardine. Harbors are classified from West to East (Málaga (Northern Alboran Sea); Torrevieja, Tarragona (Northern Spain area); Sète (Gulf of Lions); Chioggia, Porto Garibaldi, Ancona, San Benedetto, Split (Adriatic Sea)). Statistical significances of correlation are indicated by bold values.

\begin{tabular}{|c|c|c|c|c|c|c|c|c|c|}
\hline & Málaga & Torrevieja & Tarragona & Sète & Chioggia & $\begin{array}{l}\mathrm{P} . \\
\text { Garibaldi }\end{array}$ & Ancona & $\begin{array}{l}\text { S. } \\
\text { Benedetto }\end{array}$ & Split \\
\hline Málaga & & NA & 0.24 & 0.18 & 0.10 & 0.24 & 0.28 & 0.24 & 0.17 \\
\hline Torrevieja & 0.44 & & NA & NA & $\mathrm{NA}$ & $\mathrm{NA}$ & $\mathrm{NA}$ & $\mathrm{NA}$ & $\mathrm{NA}$ \\
\hline Tarragona & 0.29 & 0.46 & & 0.41 & 0.26 & 0.18 & 0.35 & 0.36 & 0.33 \\
\hline Sète & 0.41 & 0.41 & 0.65 & & 0.38 & 0.21 & 0.30 & 0.48 & -0.02 \\
\hline Chioggia & 0.30 & 0.23 & -0.04 & 0.33 & & 0.51 & 0.51 & 0.49 & 0.19 \\
\hline P. Garibaldi & 0.23 & 0.21 & 0.02 & 0.39 & 0.70 & & 0.55 & 0.44 & 0.37 \\
\hline Ancona & 0.31 & 0.36 & 0.20 & 0.41 & 0.68 & 0.68 & & 0.50 & 0.33 \\
\hline S. Benedetto & 0.15 & 0.25 & 0.45 & 0.23 & 0.45 & 0.50 & 0.66 & & 0.43 \\
\hline Split & NA & NA & NA & NA & NA & $\mathrm{NA}$ & NA & NA & \\
\hline
\end{tabular}

